U. S. DEPARTMENT OF AGRICULTURE BIOLOGIOAL SURVET-BULLETIN No. 37

HENRY W. HENSHAW, Chief

\title{
FOOD OF THE WOODPECKERS OF THE UNITED STATES
}

BY

F. E. L, BEAL

Assistant, Biological Survey

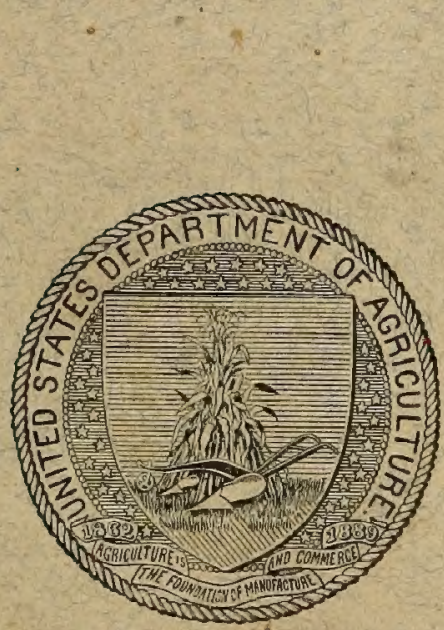

WASHINGTON

GOVERNMENS PRINTING OFEICE 1911 


\section{Cornell University Library}

The original of this book is in the Cornell University Library.

There are no known copyright restrictions in the United States on the use of the text.

http://www.archive.org/details/cu31924090316021 



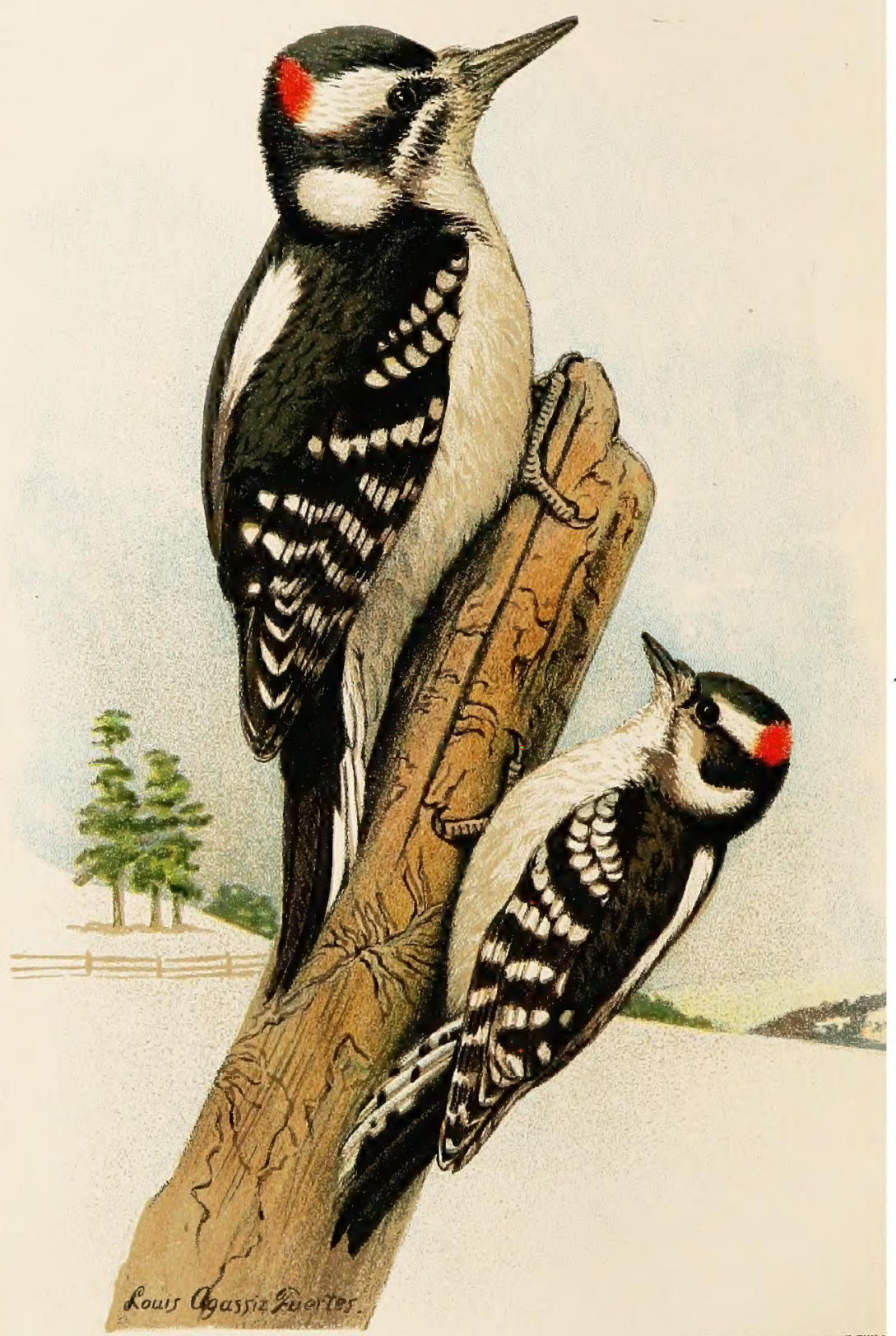

BREUKFR \& KESSLER CO LITH DHIL

HAIRY AND DOWNY WOODPECKERS. 


\title{
U. S. DEPARTMENT OF AGRICULTURE
} BIOLOGICAL SURVEY-BULLETIN No. 37

HENRY W. HENSHAW, Chief

\section{F00D OF THE WOODPECKERS OF THE UNITED STATES}

\author{
BY \\ F. E. L. BEAL \\ - Assistant, Biological Survey
}


ORNITH

Fuertes

QL

690

P56

P. 41

1911 


\title{
LETTER OF TRANSMITTAL.
}

\author{
U. S. Department of Agriculture, \\ Biological SurveY, \\ Washington, D. C., December $23,1910$.
}

SIR: I have the honor to transmit herewith for publication as Bulletin No. 37 of the Biological Survey, a report on the Food of the Woodpeckers of the United States, by F. E. L. Beal, assistant, Biological Survey. The diminished supply of timber and its greatly increased cost render the conservation of our remaining forests exceedingly important. It has been estimated that within the United States insects destroy trees and lumber to the value of upward of $\$ 100,000,000$ annually. As boring insects are the natural enemies of trees, so birds are their natural allies. Of all birds that further the welfare of the forest; woodpeckers are the most important, many of them indeed being specially adapted to dig into wood in order to reach insect larvæ safe from all other enemies. While most woodpeckers are thus highly beneficial, the sapsuckers are injurious, since they subsist to a considerable extent on the cambium or inner bark of trees. This bulletin is meant to serve a practical end by describing the food habits of the several species, and by pointing out the extent to which each is beneficial or injurious, so that the forester, the farmer, and the orchardist may know friend from foe.

Respectfully,

Hon. JAMES WiLson,

H. W. Henshaw, Chief, Biological Survey.

Secretary of Agriculture. 



\section{CONTENTS.}

\begin{tabular}{|c|c|}
\hline \multicolumn{2}{|l|}{ 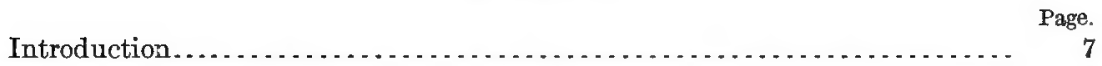 } \\
\hline airy woodpecker $\ldots \ldots \ldots \ldots \ldots \ldots \ldots$ & 13 \\
\hline woodpecker.. & 17 \\
\hline pecker....... & 22 \\
\hline . & 23 \\
\hline$\Delta \Gamma$ & 25 \\
\hline er or sapsucker......... & 27 \\
\hline .......... & 31 \\
\hline 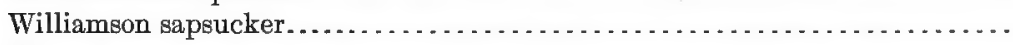 & 32 \\
\hline - & 33 \\
\hline 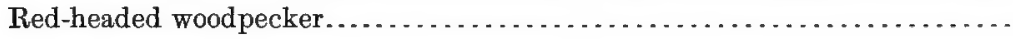 & 35 \\
\hline ali & 43 \\
\hline ( & 45 \\
\hline & $\mathbf{T}$ \\
\hline 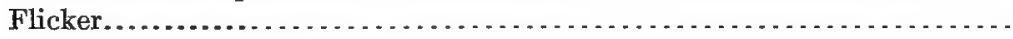 & 52 \\
\hline 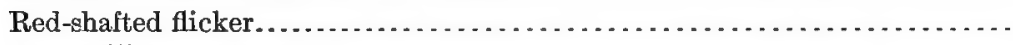 & 59 \\
\hline & 62 \\
\hline ther woodpeckers... & 63 \\
\hline
\end{tabular}




\section{L LUSTRATIONS.}

PLATES.

Page

Plate I. Hairy and downy woodpeckers................... Frontispiece.

II. Yellow-bellied sapsucker. ............................ 32

III. Red-headed woodpecker................................ ${ }_{32}$

IV. California woodpecker............................... 40

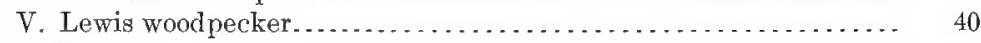

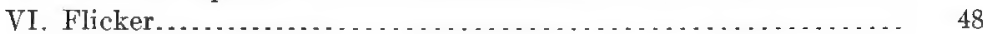

TEXT FIGURES.

Fic. 1. Tongues of woodpeckers............................... 8

2. Special development of tongues of woodpeckers................ 8

3. Wood from which woodpecker has extracted insect............. 9 


\title{
FOOD OF WOODPECKERS.
}

\author{
(Picidæ.) \\ INTRODUCTION.
}

During the last few decades much interest has been aroused in the preservation and extension of forest areas within the United States, and large sums of money have been spent on our National Forests. Meanwhile scientists have been studying means to combat the insect enemies of forests, which in some cases have threatened the total destruction of large tracts. There is probably no species of land plant that has not at least one insect enemy, and the trees of the forest furnish food and homes for legions. In the Fifth Report of the United States Entomological Commission over 400 species of insects are reported to feed on the oak, and the opinion is expressed that this number is far below the total. In the same work about 80 species are said to feed on the elm, 170 on the hickory, 41 on the locust, 100 on the maple, 105 on the birch, 186 on the willow, and 165 on the pine; and in each case the list is confessedly incomplete.

On this point Dr. Hopkins has said:

The results of investigation lead to the conclusion that the annual loss from insect work on forest trees, and their crude or finished products, amounts to at least $\$ 100,000,000$.

No period in the life history of a tree is exempt from insect attack, and every part, from the smallest roots to the terminal buds, leaves, flowers, and fruit, may be infested by one or many species. The seed in the ground, the tender shoots of both roots and stems, and the young seedling to the matured tree, may be attacked by special enemies which injure or destroy different parts of the entire plant. In fact, living, diseased, dead, or decaying, a tree may be the home of hundreds of species and thousands of individuals of insect life. ${ }^{1}$

Wherever the Dendroctonus beetles have been found in standing timber, the work of woodpeckers has been more or less common, and in some trees quite a large percentage of the beetle broods has been destroyed by the birds. The evidence gathered in Maine a few years ago indicates quite conclusively that the birds were rendering a most valuable service as a natural check to the multiplication and destructive work of the eastern spruce beetle. The work of birds is common in sections where species 1 [Dendroctonus brevicomis], 9 [D. monticolæ], and 10 [D. ponderosæ], and other western species are prevalent. Yet birds evidently render the greatest service where but few trees are being killed, since their concentrated work may prevent an abnormal increase of the beetles; but where many hundreds or thousands of trees are being killed, the limited number of birds can have little or no effect. Therefore, while the birds are among the foresters' valuable friends, they can not, even with the utmost protection, always be relied upon to protect the forest from its enemies. ${ }^{2}$

1 From manuscript of lecture on Forest Insects and Their Destructive Work, by Dr. A. D. Hopkins, in charge of Forest Insect Investigations, Bureau of Entomology, U. S. Dept. Agric.

2 Hopkins, A. D., Bull. 83, Bureat of Entomology, U. S. Dept. Agric., Part I, pp. 27-28, 1909. 
From these considerations it is at once apparent how important must be any agency that restrains or limits this great army of tree destroyers. Of all birds that further the welfare of trees, whether

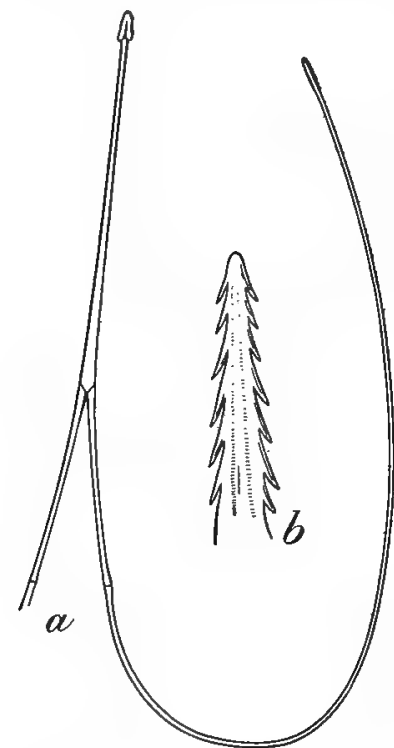

Fig. 1.-Tongues of woodpeckers. of forest or orchard, woodpeckers are the most important. The value of their work in dollars and cents is impossible to calculate, but careful study of their food in both field and laboratory has brought out many facts of practical importance.

Wondpeckers are essentially arboreal in their habits and obtain the greater part of their food from trees. Their physical conformation eminently adapts them to this mode of life. Their legs are rather short and stout, and the toes are furnished with strong, sharp claws. With the exception of the genus Picoides, all North American woodpeckers have four toes, two of which point forward and two backward. To further aid in maintaining themselves on the trunks of trees, their tails are composed of stiff feathers terminating in sharp spines, which can be pressed against the bark and so serve as a prop to hold the bird in an upright positjon while it is at work. Woodpeckers are thus enabled to cling easily to the trunks and branches and to strike effective blows with their beaks upon the bark or wood

As much of the food of woodpeckers is obtained from solid wood, Nature has provided most of them with a stout beak having a chisel-shaped point, which forms an exceedingly effective wood-cutting instrument. But the most peculiar and interesting point in the anat-

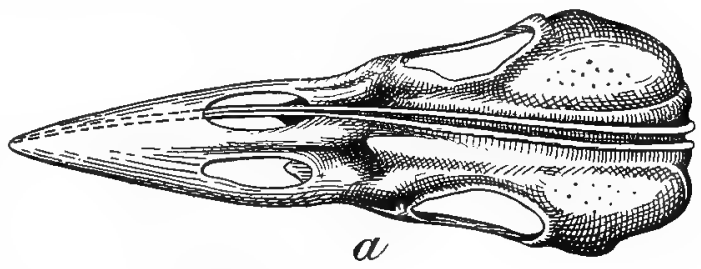
omy of these birds is the tongue. This is more or less cylindrical in form and usually very long (fig. 1, a). At the anterior end it generally terminates in a hard point, with more or less barbs upon the sides (fig. 1, b). Posteriorly the typical woodpecker tongue is 
extended in two long, slender filaments of the liyoid bone which curl up around the back of the skull and, while they commonly stop between the eyes, in some species they pass around the eye (fig. $2, b$ ), but in others enter the right nasal opening and extend to the end of the beak (fig. $2, a$ ). In this last case the tongue is practically twice the length of the head. Posteriorly this organ is inclosed in a muscular sheath by means of which it can be extruded from the mouth to a considerable length, and used as a most effective instrument for dislodging grubs or ants from their burrows in wood or bark. Hence, while most birds have to be content with such insects as they find on the surface or in open crevices, the woolpeckers devote their energies to those larva or grubs which are beneath the bark or even in the heart of the tree. They locate their hidden prey with gieat accuracy and often cut small holes directly to the burrows of the grubs. In

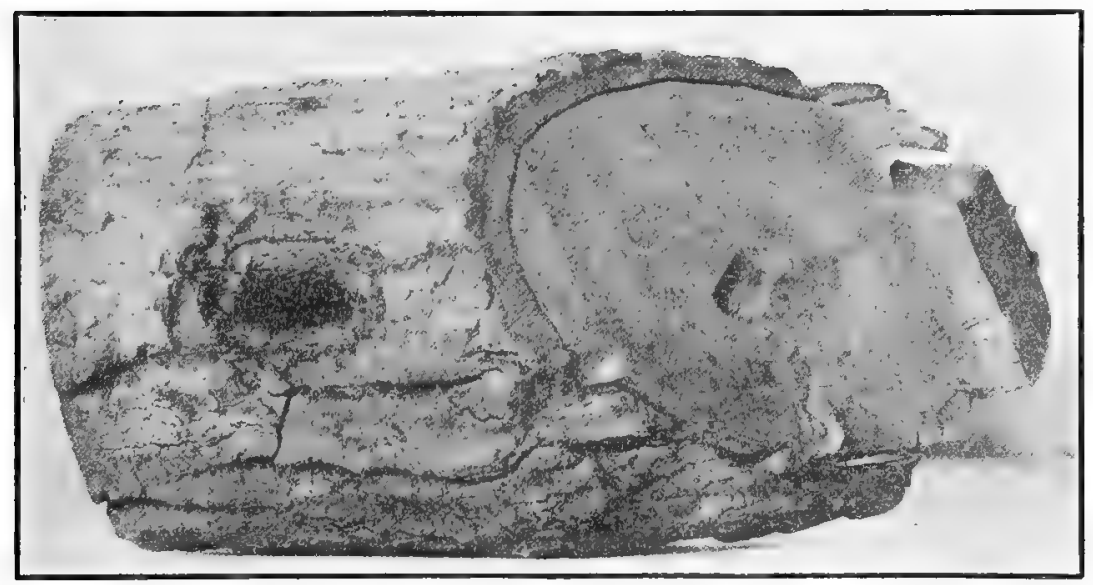

FIG. 3.-Wood from which woodpecker has extracted insect.

figure 3 the grub had eaten a burrow through the heart of a maple sapling, but its position was accurat ely letermined by the bird, which then cut through the solid live wood until it reached the burrow and extracted the insect.

In the United States, exclusive of outlying possessions, there are about 45 species and subspecies of this family, most of which are of decided economic importance. As a family they are much less migratory than most other birds, and a majority of the species occuly the same range throughout the year, which adds materially to their value to farmers. Their food consists so largely of wood-boring grubs, hibernating insects, and insects' eggs and pupæ that their supplies do not fail even in the coldest weather.

The present paper is based upon the examination of 3,453 stomachs of woodpeckers representing 16 species and nearly twice as many subspecies, taken in all parts of the United States, with a few from Canada. In the following table the species are arranged in the 
order of the average amount of animal food contained in their stomachs.

Name of species.

Three-toed woodpecker (Picoides americanus).

Arctic three-toed woodpecker ( $P$ icoides arcticus).

Williamson sapsucker (Splyrapicus thyroideus).

Red-cockaded woodpecker (Dryobates borealis).

Nuttall woodpecker (Dryobates nuttalli)...

Hairy woodpecker (Dryobates villosus).

Downy woodpecker (Dryobates pubescens)

Pileated woodpecker ( $P$ hlocotomus pileatus)

Red-breasted sapsucker (Sphyrapicus ruber)

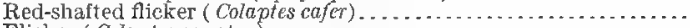

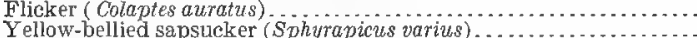

Lewis woodpecker ( $A$ sundesmus lewisi).

Red-loeaded woodpecter ( Melenterpas

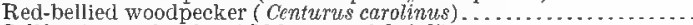

California woodpecker ( Melanerpes f. bairdi).

Total.

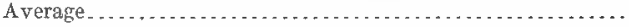

\begin{tabular}{|r|c|c}
$\begin{array}{c}\text { Number of } \\
\text { stomachs. }\end{array}$ & $\begin{array}{c}\text { Per cent of } \\
\text { animal } \\
\text { food. }\end{array}$ & $\begin{array}{c}\text { Per cent of } \\
\text { vegetable } \\
\text { food. }\end{array}$ \\
\hline 23 & 94.06 & 5.94 \\
28 & 88.69 & 11.31 \\
17 & 86.67 & 13.33 \\
76 & 81.06 & 18.94 \\
53 & 79.41 & 20.59 \\
382 & 77.67 & 22.33 \\
723 & 76.05 & 23.95 \\
80 & 72.88 & 27.12 \\
34 & 68.92 & 31.08 \\
183 & 67.74 & 32.26 \\
684 & 60.92 & 39.08 \\
313 & 49.31 & 50.69 \\
59 & 37.48 & 62.52 \\
443 & 33.83 & 66.17 \\
271 & 30.94 & 69.06 \\
84 & 22.59 & 77.41 \\
\hline 3,453 & $\ldots \ldots$ & \\
\hline$\ldots$ & 64.26 & 35.74 \\
\hline
\end{tabular}

It is not probable that these relations are absolute in every case. The position of Sphyrapicus ruber above the two species of Colaptes is perhaps accidental, and the examination of a few stomachs more or less would be likely to change slightly the relative positions. The vegetable food, of course, stands in an inverse ratio to the animal. Mineral matter (sand) is not taken largely by woodpeckers. The most is found in the stomachs of the flickers, but it is probably picked up accidentally with ants, of which these birds eat great numbers. Ants constitute the largest item of animal food-28.41 per cent, considering the whole 16 species collectively--and are actually the largest item in the stomachs of 8 species. The Williamson sapsucker, the red-cockaded woodpecker, and the two flickers take the highest rank in this respect. Beetles stand next in importance, and amount to 20.42 per cent. These two items together form nearly half the food. The remainder of the animal food is composed of insects, with a few spiders, millepeds, and sowbugs, and occasionally a salamander, tree frog, lizard, or snail. In the following table is given the average percentage of ants and beetles in the stomach. The species are arranged in the order of their rank as ant eaters.

\begin{tabular}{|c|c|c|}
\hline Name of species. & $\begin{array}{c}\text { Per cent of } \\
\text { ants. }\end{array} \mid$ & $\begin{array}{c}\text { Per cent of } \\
\text { beetles. }\end{array}$ \\
\hline 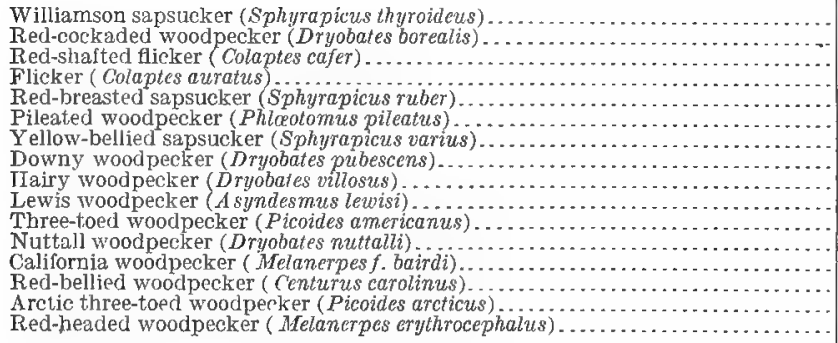 & $\begin{array}{l}85.94 \\
56.75 \\
53.82 \\
49.75 \\
42.49 \\
39.91 \\
34.31 \\
21.36 \\
17.10 \\
11.87 \\
8.29 \\
8.19 \\
8.09 \\
6.45 \\
\text { 0. } 35 \\
5.17\end{array}$ & $\begin{array}{r}0.13 \\
11.02 \\
6.55 \\
5.14 \\
4.02 \\
22.01 \\
6.02 \\
21.55 \\
41.42 \\
9.12 \\
71.05 \\
28.86 \\
2.67 \\
10.18 \\
67.66 \\
18.85\end{array}$ \\
\hline Average. . & 28.49 & 20.39 \\
\hline
\end{tabular}


If the 16 species of woodpeckers herein discussed were arranged in the order of their usefulness according to their food, they would stand about as at top of page 10, except that the 3 species of Sphyrapicus, owing to their sap-sucking propensities, might be placed at the foot of the column. It is unfortunate that so few stomachs of the three or four species nearest the top have been received, but probably those examined were in no way exceptional. The 2 species of Picoides are among the most useful birds, especially in the forest, of which they are preeminently the conservators. More than 60 per cent of the animal food of these two birds consists of the larvæ of wood-boring beetles, which they dig from the bark and wood of trees. The two species Dryobates pubescens and $D$. villosus do not fall far behind in this good work, and several others eat very appreciable quantities of wood borers. Among the beetles eaten by the different birds are naturally some useful species, such as the predaceous ground beetles (Carabidæ) or tiger beetles (Cicindelidæ). The redhead eats useful beetles to the extent of 7.34 per cent of its diet, the Lewis woodpecker, with 6.7 per cent, stands next on the list of offenders in this respect, followed by the red-shafted flicker with 3.9 per cent, and the eastern flicker with less than 2 per cent. No other species had eaten so much as 1 per cent of these beetles. Whatever sins woodpeckers may commit, the destruction of useful beetles is not one of them.

Nearly all the vegetable food, except a few seeds, including some grain, can be included under three items -fruit, cambium, and mast. The greatest interest attaches to the cambium, which is a jellylike substance found just under the bark of growing trees and from which both wood and bark are formed. The smaller species of woodpeckers have been accused of pecking the bark from fruit and forest trees to an injurious extent in order to get this substance. While nearly all members of the family eat some cambium, the only ones that really do much harm by the habit appear to be the yellowbellied sapsucker (Sphyrapicus varius) and others of the same genus. With the yellow-bellied sapsucker cambium amounts to about 17 per cent of the annual food and in April reaches 48 per cent. As the substance is often semifluid, probably much passes almost immediately out of the stomach, leaving only the harder and less easily digested part, so that a much larger amount is eaten than is shown by stomach examination.

In obtaining the cambium the bird sometimes denudes the tree of its bark over a considerable area, and so ruins it for any economic use except fuel; at other times a series of single punctures are made in lines extending around the tree, and as new layers of wood grow over these, the indentation at each puncture becomes less and less pronounced. If, after some years, this timber be cut and sawed, 
a tangential or circular cut across the punctures gives a bird's-eye appearance very similar to that which Nature produces in some maples. A radial cut through the punctures gives the curly look often found in many woods. It frequently happens, however, that water enters at the punctures and causes a slight decay; which usually disfigures the wood by making a dark stain, though occasionally the effect is ornamental.

With the possible exception of the crow, no birds have been subject to so much adverse criticism as the woodpeckers. When they are seen scrambling over fruit trees and fresh holes are found in the bark, it is concluded that they must be doing harm. But woodpeckers, except a few species, rarely disfigure a healthy tree, but when they find a tree infested by wood-boring larvæ, they locate the insects accurately, draw them out, and devour them. If in succeeding years the burrows formerly occupied by the larvæ are used by a colony of ants, they in turn are dug out and destroyed.

The following are samples of testimony by Dr. Hopkins and other eminent entomologists to the persistent and effective work of woodpeckers in destroying wood-boring beetles and other insect enemies of trees:

As has already been stated, woodpeckers are the most important enemies of the bark beetle, and appear to be of inestimable value to the spruce-timber interests of the Northeast. Indeed, I feel confident that in the many hundreds of infested trees examined at least one-half of the beetles and their young had been destroyed by the birds, and in many cases it was evident that even a greater proportion had perished from this cause alone.

Estimating 100 beetles to the square foot of bark in the average infested tree, and an average of 60 square feet of infested bark, it is possible for each tree to yield an average of 6,000 individuals; 100 trees, 600,000 , and so on. It is therefore plain that, if one-half or two-thirds of this number are destroyed by the birds and other enemies, the amount of timber the remainder can kill will be lessened. This is all the more apparent when it is remembered that it is only when the beetles occur in great numbers that they can overcome the resistance of the living trees. ${ }^{1}$

Birds contribute their share, also, in destroying larvæ and pupæ. The work of woodpeckers was found upon most of the trees which had been killed by Dendroctonus brevicomis, and these birds had evidently destroyed a large percentage of the insects in some of the trees, ${ }^{2}$

As natural enemies of this insect [the maple borer, Plagionotus speciosus] it is probable that various species of woodpeckers render the greatest service. At Huntington, Mass., I have seen the hairy woodpecker, the downy woodpecker, and the flicker feeding upon white larvæ taken from beneath the bark of maples infested by this borer. ${ }^{3}$

Woodpeckers do much good by hammering holes in the bark of infested cottonwoods and devouring the young carpenter worms [larvæ of Cossus populi]. We certainly ought to protect these feathered friends of ours instead of allowing every small boy in the country to shoot them whenever he pleases. ${ }^{4}$

\footnotetext{
1 Hopkins, A. D., Bull. 28 (new ser.), Division of Entomology, U. S. Dept. Agric., pp. 23, 25-26, 1901.

2 Webb, J. J., Bull. 58, Part II, Bureau of Entomology, U. S. Dept. $\Lambda$ gric., p. 27, 1906.

'Kirkland, A. H., in Mass. Crop Report for June, 1897, p. 32, 1897.

4 Doten, S. B., Bull. 49, Nevada Agric. Exper. Sta., p. 12, 1900.
} 
I have found no parasite of this larva [Hepialus argenteomaculatus], but I have seen that the woodpeckers are its deadly foes. In April, 1886, I had a favorable opportunity to search for the borer and was astonished at the scores removed by these birds. They often drill through a deep layer of wood; often two holes are made one above the other, the purpose being obvious. The morsel is evidently located, or its burrow rather, by sounding, as I noticed many instances in which a row of punctures surrounded the base of the alder. The destroyers are sometimes mistaken, for I found their drillings, evidently made in search of this larva, in sound wood in which there were no borers, but these were few compared with the successful trials.

Is it the activity of these birds that prevents the abundance in the forests of certain borers, e. g. Aegeria acerni, whilst the same insect is often destructively abundant in the ornamental maples of cities and villages? ${ }^{1}$

\section{HAIRY WOODPECKER.}

\section{(Dryobates villosus subspp.)}

The hairy woodpecker (frontispiece), in one or another of its various forms, inhabits the whole of temperate North America, but is rare over some extensive areas. It is a rather restless, noisy bird, as compared with its smaller relative, the downy, and makes itself conspicuous by loud calls and rapid flights from tree to tree. It is eminently arboreal in its habits and gets most of its food from trees. While sometimes found in the midst of a dense forest, it prefers the outer edge of the woodland or groves or orchards. In the latter it is quite at home, especially if the trees be old and neglected, for then they usually offer decayed knots and limbs where wood borers establish their colonies. The bird is not migratory, unless within very narrow. limits, and where it occurs at all can usually be found the year round. It nests in a cavity which it excavates in a partly decayed trunk or branch. While often seen in the orchard, the hairy does not go there for fruit. More than three-fourths of its food consists of animal matter, and less than a fourth of the remainder is fruit, mostly of wild species.

In the investigation of the food of the hairy woodpecker detailed below, 382 stomachs were examined. They were obtained from 33 States and Territories, the District of Columbia, and Canada, and were taken in every month of the year. They undoubtedly embrace all the recognized subspecies, but as some of them were collected before all the forms had been defined, they can not now be distinguished. However, as the food of the various subspecies does not differ materially, the species has been treated as a whole. In the first analysis the food divides into 77.67 per cent of animal matter and 22.33 of vegetable. The animal food consists of insects, with a few spiders and millepeds; the vegetable part is made up of fruit, seeds, and a number of miscellaneous substances. This ratio of animal to vegetable does not vary greatly during the year, the greatest difference 
occurring in June, when the stomachs show 90 per cent of animal to 10 per cent of vegetable food. There is, however, no regular increase or decrease as the seasons change, such as is noted in birds that subsist upon flying insects and summer fruits. The wood-boring larvæ upon which this bird so largely feeds can be obtained at all times of the year, and the same is true of most of the vegetable food.

Animal food.-The largest item in the annual diet of the hairy woodpecker consists of the larvæ of cerambycid and buprestid beetles, with a few lucanids and perhaps some other wood borers. These insects constitute over 31 per cent of the food and are eaten in every month of the year. The greatest amount is taken in December, when it reaches 41 per cent of the whole; and in May, the month of least consumption, it still amounts to over 21 per cent. This shows how earnest these birds are in their efforts to procure this kind of food. In summer, insects and small fruits abound-enough to satisfy appetite and in variety apparently suited to every taste-but the birds still search for and obtain these wood-boring grubs to the extent of a fifth or more of their daily food, at the cost of hours of hard labor in digging them from the tree. One stomach contained 100 of these larvæ and 83 and 50, respectively, were taken from two others. Of the 382 stomachs, 204 , or 53 per cent, contained these grubs, and 27 of them held no other food. Other beetles amount to a little more than 9 per cent. They are distributed among a number of families, but are nearly all more or less harmful.

Weevils (Rhynchophora), or snout beetles, aggregate a little more than 3 per cent, and are mostly represented by the curculios (Curculionidæ) and engraver beetles (Scolytidæ). One of the former, Dorytomus mucidus, seems to be a farorite, as it was found in a number of stomachs, of which one contained 109 and another 63 individuals. The engravers were found in 18 stomachs. One contained 50 adults and 25 larvæ; another, 21 adults and 10 larvæ. They were of such species as Tomicus calatus and Polygraphus rufipennis. Of the latter, 17 individuals were taken from one stomach. A few carabids, or predaceous ground beetles, were also found. The average amount of these useful insects consumed is sixty one-hundredths of 1 per cent (0.60). The month of greatest consumption is March, when they are eaten to the extent of 2.46 per cent of the whole food. Evidently this bird does little harm by eating useful beetles.

Ants stand second in importance in the diet of the hairy woodpecker. They amount to a little more than 17 per cent, and are eaten in every month. In January, which is the month of greatest consumption, they reach more than 27 per cent and nearly the same in February. They are apparently eaten the least in November, when they aggregate somewhat more than 10 per cent, but this may be accidental, as both October and December show higher percentages and July practically the same. In a general way these insects 
are eaten most in winter and early spring, but every month has a good percentage. Hymenoptera other than ants are taken very irregularly and in small quantities. In September somewhat more than 5 per cent were eaten, but stomachs taken in May and December contained none at all, and the average for the year is but a little more than 1 per cent. In one stomach were found sawfly larvæ, insects which do not appear to be eaten extensively by birds.

Caterpillars are the next most important item of the hairy's food. They amount to a little less than 10 per cent, and were found in every month. The greater number were taken in August, when they aggregated nearly 19 per cent, while March showed the least, a little less than 2 per cent. Many of them were wood-boring species dug out from the wood, like the beetle larvæ. Prof. F. M. Webster states that he has seen a hairy woodpecker successfully peck a hole through the parchment-like covering of the cocoon of a Cecropia moth and devour the contents. On examining more than 20 cocoons in a grove of box elders, he found only 2 uninjured.

Bugs (Hemiptera) are evidently not a favorite food, as they were found only to the extent of 2.41 per cent for the year. June appears to be the month of greatest consumption, with somewhat less than 8 per cent, but four months show none at all, and bugs are very irregularly distributed through the rest of the year. Plant-lice (aphids) were found in 2 stomachs and scales in 4 . One of the latter was identified as the cherry or plum scale (Eulecanium cerasifex). Orthoptera, that is, grasshoppers, crickets, and cockroaches, are rarely eaten by the hairy. A few eggs, probably those of tree crickets, and the egg cases (oötheca) of cockroaches, constitute the bulk of this food. These with a few miscellaneous insects amount to a little more than 2 per cent for the year. Spiders with their cocoons of eggs, including one jointed spider (Solpugidæ), and a few millepeds, were eaten to the extent of about 3.5 . per cent, which completes the quota of animal food.

The following is a list of insects identified in the food of the hairy woodpecker: COLEOPTERA.

Agonoderus pallipes.

Ips fasciatus.

Melanotus cribricollis.

Chrysobothris sp.

Cymatodera undulata.

Lachnosterna sp

Ergates sp.

Asemum mostum.

Eleodes sp.
Nyctobates pennsylvanica.

Upis ceramboides.

Boletotherus bifurcus.

Boletophagus corticola.

Dendroides sp.

Dorytomus mucidus.

Tomicus colatus.

Polygraphus rufipennis.

HYMENOPTERA.

Ant (Camponotus pictus). 
DIPTERA.

Bluebottle fly (Phormia sp.).

HEMIPTERA.

Plum and cherry scale (Eulecanium cera- Harvest fly (Tibicen rimosa). sifex).

Vegetable food.-The vegetable food of the hairy woodpecker may be considered under four heads: Fruit, grain, seeds, and miscellaneous vegetable substances. Fruit amounts to 5.22 per cent of the food, and was contained in 54 stomachs, of which 13 held what was diagnosed as domestic varieties, and 41 contained wild species. Rubus seeds (blackberries or raspberries) were identified in 4 stomachs, and were counted as domestic fruit, but it is perhaps more probable that they were wild. Strawberry seeds (occurring in 1 stomach) and pulp (thought to be apple) were the only other cultivated varieties that could be distinguished with a reasonable degree of certainty. Evidently the hairy woodpecker does no damage by preying upon orchard or garden products. Of wild fruit 18 species were identified. It constitutes the great bulk of the fruit eaten, and is nearly all of varieties not useful to man.

Corn was the only grain discovered in the food. It was found in 10 stomachs, and amounted to 1.37 per cent. In 2 stomachs taken in August and September it was still in the milk, but all the rest was eaten in winter, so it must have been waste. Seeds of various plants had been eaten by 18 birds, but most of them were of little economic value. The seed of poison iry and poison sumac (Rhus radicans and $R$. vernix) were found in 17 stomachs, and as they usually pass through the alimentary canal uninjured, the birds do some harm by scattering the seeds of these noxious plants. The total percentage of seeds of all kinds is 4.50 .

Cambium, or the inner bark of trees, was identified in 23 stomachs. Evidently the hairy does but little damage by denuding trees of their bark. Mast, made up of acorns, hazelnuts, and beechnuts, was found in 50 stomachs. It was mostly taken in the fall and winter months, and appears to be quite a favorite food during the cooler part of the year. Dr. Merriam says that in northern New York the hairy woodpecker, like the other woodpeckers of the Adirondack region, feeds largely on beechnuts. In late fall, winter, and early spring following good yields of beechnuts, the nuts form the principal food of the woodpeckers. When grubs and ants are taken from decayed or decaying trees, bits of rotten wood, lead leaves, and other rubbish are eaten with them. Such material was found in 72 stomachs, though in most cases the percentage was small. Cambium, mast, and rubbish together constitute a little less than 11 per cent of the food. 
The following is the list of fruits and seeds identified in the food:

Foxtail grass (Ixophorus sp.).

Bayberry seed (Myrica carolinensis).

Hazelnut (Corylus sp.).

Beechnut (Fagus americanus).

Acorn (Quercus sp.).

Mulberry (Morus rubra).

Sassafras berry (Sassafras sassafras).

Spice berry (Benzoin benzoin).

Pigweed (Amaranthus sp.).

Pokeberry (Phytolacca decandra).

Vervain (Verbena sp.).

Blueberry (Vaccinium sp.).

Elderberry (Sambucus canadensis).

Sour gum (Nyssa sylvatica).

Flowering dogwood (Cornus florida).

Rough-leaved dogwood (Cornus asperifolia).
Juneberry (Amelanchier canadensis).

Northwestern Juneberry (Arrelanchier alnifolia).

Chokeberry (Aronia sp.).

Strawberry (Fragaria sp.).

Chokecherry (Prunus virginiana).

Black or rum cherry (Prunus serotina).

Woodbine berry (Parthenocissus quinquefolia).

Frost grape (Vitis cordifolia).

Sumac (Rhus glabra).

Poison sumac (Rhus vernix).

Poison ivy (Rhus radicans).

Black mustard (Brassica nigra).

Barberry (Berberis sp.).

Magnolia (Magnolia fotida).

Summary.-The foregoing analysis of the food of the hairy woodpecker shows that it is a bird from which the orchardist and forester have nothing to fear and much to gain. The quantity of useful insects or economic produce which it eats is insignificant. On the other hand, the number of destructive larvæ which it devours must have a very sensible effect in reducing the abundance of these pests.

\section{DOWNY WOODPECKER}

(Dryobates puhescens subspp.)

The downy woodpecker (frontispiece) is the smallest member of the family in the United States. With its various forms it occupies practically the whole country and extends north into British America and as far as Alaska. To the ordinary observer it is but a miniature edition of the hairy, as the plumage is practically the same. It is also a quieter bird and probably the least wary and suspicious member of the family. When busy in search of food, it pays little attention to human intruders, and often the first intimation of its presence is a gentle tapping on a dead branch or knot only a few yards away, where a colony of ants or some wood-boring larvæ have established themselves.

Like the hairy, it does not migrate, and may be found on its range at any time during the year. Owing, perhaps, to the absence of so many other birds and the leafless condition of the trees, it seems to be most conspicuous in winter. After the summer visitors have gone southward, the downy has a habit of associating with a mixed company of titmice, creepers, nuthatches, and sometimes a fow kinglets, who seem to be bound together by a community of interest in the 75713ํ-Bull. 37-11-2 
matter of food, for they all forage over the bark of the trunks and branches of trees and eat practically the same things.

The following are samples of testimony as to the good work of the downy:

The downy woodpecker, which is so common in Montana and which is so often seen in our orchards, is the fruit-grower's friend. Besides picking up miscellaneous pests it locates burrows of this borer [flat-headed apple-tree borer, Chrysobothris femorata] and extracts them in considerable numbers. In the older orchards of Montana scarcely a tree can be found that does not bear the marks of woodpeckers, a large proportion of which are made by this species. ${ }^{\text {I }}$

Mr. E. Dwight Sanderson, in speaking of the work of the downy woodpecker, says:

$\mathrm{He}$ is the arch enemy of the codling moth and were it not for his good offices in destroying the larvæ in the winter your apple crop might frequently be a failure. ${ }^{2}$

Prof. Samuel Aughey examined four stomachs of the downy woodpecker in Nebraska, all of which contained grasshoppers.

The late Dr. Townend Glover, entomologist of the Department of Agriculture, states that the stomach of a downy woodpecker shot in February "was filled with black ants." He states further:

On one occasion a downy woodpecker was observed by myself making a number of small, rough-edged perforations in the bark of a young ash tree, and upon examining the tree when the bird had flown it was found that wherever the bark had been injured the young larvæ of a wood-eating beetle had been snugly coiled underneath, and had been destroyed by the bird. ${ }^{3}$

In the laboratory investigation of the food of the downy woodpecker 723 stomachs were examined. They were collected in 33 States, the District of Columbia, and Canada. They are quite regularly distributed over the 12 months of the year, and probably represent fairly the average annual food. This is made up of 76.05 per cent of animal matter to 23.95 per cent of vegetable.

Animal food.-Beetles taken collectively amount to 21.55 per cent, and are the largest item of the food. Of these, a little less than 14 per cent are wood-boring larvæ, principally cerambycids, with some buprestids. They were found in 289 stomachs, or about 40 per cent of all, and 10 contained no other food. This is only about half the amount found in the stomachs of the hairy woodpecker, and shows that the downy pecks wood much less than the hairy. These larvæ are eaten at all times of the year, though the most are taken in the cooler months. In November they constitute 20 per cent of the food, which is the maximum, though in the other fall months and in the winter and spring months they do not fall far below. In June the minimum of 4.5 per cent was eaten. The economic value of the destruction of these larvæ is very great.

\footnotetext{
1 Cooley, R. A., Bull. 51, Montana Agric. Exper. Sta., p. 226, 1903.

2 Bull, 131, New Hampshire Agric. Exper. Sta, p. 18, 1907.

3 U. S. Commissioner of Agric., Rept. for 1865, pp. 37-38, 1866.
} 
Weevils amount to a little more than 3 per cent, but appear to be a rather favorite food, as they were found in 107 stomachs, and 4 contained 50, 36, 34, and 33 adult individuals, respectively, whife in another were 100 in the pupal stage. The engravers (Scolytidæ) were identified in 12 stomachs. Other beetles aggregate a little less than 5 per cent of the food, and are all more or less harmful except a few carabids, which amount to 0.80 per cent for the year.

Ants are eaten by the downy to the extent of 21.36 per cent of its diet, and are taken more regularly than any other element of the food. October, with 9.85 per cent, appears to be the month of minimum consumption, but it is doubtful if this would always hold, as every other month shows at least twice this amount. Hymenoptera other than ants are eaten very sparingly by the downy. They aggregate only 1.18 per cent, and in June, the month of greatest consumption, amount to only 2.45 per cent, while none were found in the 28 stomachs taken in May.

Iemiptera, or bugs, were found in 111 stomachs, and constitute 8.57 per cent of the food. Scales, or bark lice, were found in 41 stomachs and aphids, or plant lice, in 20 . A collection of 10 stomachs taken in Maine in March contained from 90 to 100 per cent of scales, the average for 10 stomachs being 93.10 per cent. This would seem to indicate that where these insects abound, the birds collect and feed upon them almost exclusively. Scales and plant lice together amount to 2.85 per cent of the yearly food. Four genera and two species of scales were identified. Bugs of various other species reach a little less than 6 per cent.

Caterpillars appear to be a very acceptable food for the downy woodpecker, as they constitute 16.50 per cent of the yearly diet. A large proportion of them are of the wood-boring species, and were evidently dug out of the wood, the same as the beetle larvæ. Others are surface feeders taken from leaves and bark. In this connection the greatest interest attaches to the pupæ and larvæ of the codling moth, generally recognized as the worst pest of the apple orchard. These insects, in one stage or the other, were identified in 8 stomachs. While this is a small number, the wonder is that the bird gets them at all. The eggs are minute, and as soon as they hatch the larvæ bore into the fruit, where they feed in security, though it is claimed by some. observers that woodpeckers sometimes dig them out. When full grown, they leave the apple and crawl into some cranny, where they change to pupæ. It is in this condition, $\dot{i}$. e., as larvæ full grown or pupæ, that they are secured by the birds. One stomach of the downy contained 18, and another 16 of these grubs. As the adult moth flies by night and lies hidden during the day, it is probably not often taken by birds. In any case, it would be hard to identify in the stomachs. Various insects, including grasshoppers and flies, 
make up about 2 per cent of the food. Grasshoppers, though so acceptable to many birds, were found in only 2 stomachs of the downy. On the other hand, eggs of grasshoppers, crickets, katydids, and cockroaches were identified in 48 stomachs, mostly taken in the fall and winter. Eleven stomachs from Kansas collected in December deserve special notice. Eight of them contained the eggs of grasshoppers to an arerage extent of 10 per cent of all the contents. Seven stomachs taken in Illinois in March contained grasshoppers' eggs to an arerage of over 46 per cent of the whole food. This is evidence of valuable service and emphasizes the fact that this bird resorts to the ground for food in case of necessity.

Miscellaneous insects amount to but 2.80 per cent, but among them is one that deserves particular notice. This is the immature form of the dobson (Corydalis cornutas), a large aquatic insect of nocturnal habits, seldom seen except when it approaches a bright light. The larræ are commonly known as hellgramites, and are usually found under stones in the beds of streams, though sometimes seen among wet rubbish near water. How a woodpecker could obtain these creat ures is a mystery, but 1 stomach of the downy contained the remains of at least $t$ of the larvæ, and in another was 1 in the pupal stage.

Spiders, millepeds, pseudoscorpions, sowbugs, and a few snails aggregate 4.09 per cent, and complete the quota of the animal food.

The following is a list of insects identified in the food:

COLEOPTERA.

Amara sp.

Gynandropus hylacis.

Sitt nolophus sp.

Ips fasciatus.

Tenebrioides bimaculata.

Dolopius lateralis.

Ielanotus sp.

Chrysobothris sp.

C'atorama sp.

Aphodius inquinatus.

Elaphidion sp.

Rhagium lineatum.

Obereasp.

Diachus auratus.

Gastroidea cyanea.

Melasoma californica.
Platydema sp.

Helops areus.

Votoxus alamedx.

Pandeletejus hilaris.

Dorytomus mucidus.

Dorytomus breticollis.

Desmoris constrictus.

Gymnetron teter.

Conotrachelus naso.

C'ryptorhynchus ferratus.

Centrinus sp.

Balaninus sp.

Xyloterus bivittatus.

Hylesinus aculeatus.

Piezocorynus mixtus.

HYIENOPTERA.

Ants (Camponotus marginatus and $r$. pennsyluanicus).

LEPIDOPTERA.

Tent caterpillar ( Iralarnsoma sp.).

Codling moth (Carpocapsa pomonella).

Cotton bollworm (Heliothis obsoletus). 
HEMIPTERA.

False chinch bug (Piesma cinerea). Red bug (Largus succinctus). White scale (Aspidiotus sp.).
Oak scale (Kermes sp.).

Olive scale (Saissetia olex).

Plum and cherry scale (Eulecanium cerasifex).

ORTHOPTERA.

Large meadow grasshopper (Orchelimum glaberrimum).

NEUROPTERA.

Dobson (Corydalis cornuta).

Vegetable food.-Fruit was eaten to the extent of 5.85 per cent of the whole food. Mlost of it is of useless wild varieties. Ten species were identified by their seeds, of which the Rubus fruits, i. e., raspberries or blackberries, might have been cultivated, but probably were not. They were found in only 1 stomach. A number of stomachs contained fruit pulp, which could not be further identified and may have been cultivated. Corn was found in 20 stomachs, most of it taken in the winter and early spring months, so that it was waste grain, except that found in 2 stomachs in August and September, which was probably in the milk. A few other stomachs held what was thought to be grain of some kind, but was too finely ground for further identification. Grain of all kinds aggregates 1.66 per cent.

The poison Rhuses (Rhus radicans, $R$. vernix, R. diversiloba, and $R$. toxicodendron) seem to afford a favorite winter food for many birds. While the seeds themselves are so thoroughly protected by a hard, horny coating that they are seldom broken in the stomachs, they are overlaid by a white waxy pulp, which easily comes off, and is probably very nutritious. These seeds were found in 86 stomachs of the downy woodpecker, and they amount to 5.93 per cent of the food. Unfortunately they germinate freely after they have been voided, and probably these birds are the most efficient agents in distributing these noxious plants. Mast, i. e., acorns, beechnuts, chestnuts, hazelnuts, chinquapins, with a few other smaller seeds, amounts to 8.20 per cent of the food. This food is eaten in every month-the most in January and the least in July. A little cambium and some rubbish make up the remainder of the vegetable food, 2.31 per cent. The charge sometimes made that the downy injures trees by eating the inner bark is disproved. It eats cambium rarely and in small quantities.

The following seeds and fruits were found in the downy's food:

Bayberry (Myrica caralinensis).

Hornbeam (Ostrya virginiana).

Beech (Fagus americanus).

Oak (Quercus sp.).
Sorrel (Rumex sp.).

Smartweed (Polygonum sp.).

Pokeweed (Phytolacca decandra).

Blackberry or raspberry (Rubus sp.). 
Mountain ash (Sorbus americana).

Juneberry (Amelanchier canadensis).

Poison iry (Rhus radicans).

Poison oak (Rhus diversiloba).

Thodbine (Parthenocissus quinquefolia).

Flowering dogwood (Cornus florida).

Rough-leaved dogwood (Cornus asperifolia).
Alternate-leaved dogwood (Cornus alternifolia).

Mullein (Verbascum thapsus).

Elderberry (Sambucus canadensis).

Sunflower (Helianthus sp.).

Blueberry (Iaccinium sp.).

Summary. - The foregoing discussion of the food of the dowuy woodpecker shows it to be one of our most useful species. The only complaint against the bird is on the score of disseminating the poisonous species of Rhus. However, it is fortunate that the bird can live on this food when it is difficult to procure anything else. The insect food selected by the downy is almost all of species economicaliy harmful.

\section{RED-COCKADED WOODPECKER.}

(Dryobates borealis.)

The red-cockaded woodpecker is an inhabitant of the Lower Austral zone of the Southeastern States from southern Virginia to eastern Texas and southern Missouri. Pine woods are its favorite haunts, and a large percentage of its food is obtained from pine trees. No complaints hare yet been heard that this bird harms crops or forest trees, nor do the contents of its stomach indicate that such is the case. So lar as known, it does not frequent orchards or cultivated land.

In the inrestigation of this bird's food 76 stomachs were arailable, taken in the four States of Alabama, Florida. Louisiana, and Texas. They were collected in erery month except June and July. Of the total food 81.06 per cent was composed of insects, and the remainder, 18.94 per cent, of vegetable matter, mostly seeds of conifers.

Animal food.--Useful Coleoptera, i. e., carabids, were found in 7 stomachs, and amount to 0.53 per cent of the whole food. Other beetles, a large part of them the larrix of wood-boring species, aggregate 10.49 per cent of the annual diet. Of these a number were weevils or snout beetle's. Of the two identified bectles in the list which follows, the first belongs to the Chrrsomelidæ or leaf-eating beetles; the other, Trogosita virescens, is one of the most beneficial species, since it preys upon the more destructive bark beetles and bark-boring grubs. Ants are eridently the favorite food. They were eaten in every month of which we have a record, and amount to a good percentage in each. December, with a percentage of 27.43 , was apparently the month of least consumption, and September shows the maximum of 79 per cent, but we have hardly enough data to obtain final figures. The average for the year is 56.75 per cent, a record which is exceeded by that of only one other bird yet studied. 
Hemiptera are eaten to the extent of 8.16 per cent of the food, and a good proportion of them are scales or bark lice. The others are mostly pentatomids or soldier-bugs. Nearly all were taken in the five months from December to April, inclusive, and two-thirds of them in December and January. These insects, and especially the pentatomids, are lovers of warm weather and sunshine, and many of them live on fruit. It seems probable that this bird gets them from their hibernating places. Grasshoppers, crickets, cockroaches, caterpillars, white ants (Termes), and spiders make up the rest of the animal food, 5.13 per cent. The cockroaches were in the form of their egg cases (oötheca).

The following is a list of insects identified in the stomachs: COLEOPTERA.

Gastroidea sp.

Trogosita virescens.

Ant (Camponotus socius).
Trogosita chloridea. Tomicus cacographus.

HYMENOPTERA.

Ant (Cremastogaster læviuscula).

\section{HEMIPTERA.}

Green tree bug (Nezara hilaris).

Vegetable food.-The greater part of the vegetable food consists of mast, mostly composed of the seeds of conifers. They were found in 26 of the 76 stomachs, and appear to be a somewhat regular article of diet, especially in the colder months. The total amount for the year is 11.13 per cent. Fruit pulp, poison-ivy seeds, bayberry seeds, seeds not identified, cambium, and rubbish each occurred in a few stomachs, and altogether amount to about 8 per cent of the food. Fruit pulp was found in 5 stomachs, but none of it could be further identified. Cambium was contained in 4 stomachs, and seeds of poison ivy in 1 . Evidently this food has little economic interest.

The following seeds were identified in the food:

Bayberry (Myrica carolinensis).

Poison ivy (Rhus radicans).
Magnolia (Magnolia fretida). Pine (Pinus sp.).

Summary.-From this brief review of the food of the red-cockaded woodpecker it is evident that it does little if any damage by eating products of husbandry, and that it does good work in the forest by devouring wood-boring larvæ. No doubt it aids in distributing the seeds of the pines upon which it feeds.

\section{NUTTALL WOODPECKER.}

(Dryobates nuttalli.)

This bird is much like the downy in its quiet demeanor, its lack of fear of man, and its unobtrusive industry in searching for food. It is only a trifle larger than the downy, and its foraging and nesting 
habits are similar. Its range is practically confined to California, though it extends slightly beyond the boundaries at the northern and southern ends of the State.

The food of the Nuttall is much like that of the downy, the principal difference being in the relative proportions of the constituents. Only 53 stomachs of the Nuttall were available for examination-entirely ton few to furnish final results, but enough to give an idea of the general character of the food. In the first analysis the food divides into 79.41 per cent of animal matter and 20.59 of vegetable. This differs but little from the record of the downy.

Animal food.--The largest item in the diet of the Nuttall consists of beetles of several families. The total for the year is $28.86 \mathrm{per}$ cent. Of these the useful Carabidæ are barely represented. The remainder are divided among about a dozen families, of which the very harmful Cerambycidæ and Elateridæ in the larval stage are the most prominent. Ants amount to 8.19 per cent and are unevenly distributed, and the indications are that the stomachs are entirely too few to give trustworthy data on this item. Hymenoptera other than ants were eaten to the extent of 3.50 per cent. This again is not a reliable result, as nearly all of them were found in one stomach taken in December. Hemiptera, or bugs, amounted to $14.76 \mathrm{per}$ cent. A few of these were scales and plant lice, but the majority were of the larger species. Two stomachs contained each between 30 and 40 box-elder bugs (Leptocoris trivittatus). These insects have a way of becoming very abundant at times and making a nuisance of themselves by invading buildings in search of winter quarters. Caterpillars stand third in the dietary of the Nuttall woodpecker and are eaten more regularly than any other food except beetles. They amount to 14.21 per cent. No special pest was identified, but some were evidently wood-boring species. A few flies, raphidians, pseudoscorpions, spiders, and millepeds make up the rest of the animal food, 9.89 per cent.

Following is a list of insects identified in the stomachs of the Nuttall:

COLEOPTERA.

Glyptoscelis albidus.

Gastroidea sp.

Sinea diadema.
Blapstinus sp.

Balaninus sp.

HEMIPTERA.

Leptocoris trivittatus.

ISOPTERA.

White ant (Termes sp.).

Vegetable food.-Fruit was eaten to the extent of 8.49 per cent. It was found in 15 stomachs, of which 2 contained rubus seeds; 5 , elderberries; and the rest, pulp not further identified, except that 
in 1 stomach it was thought to be apple. Flower buds were found in 1 stomach. Poison oak (Rhus diversitoba) was noted in 9 stomachs, mast in 5, cambium in 2 , and rubbish, etc., in 5. Altogether they amounted to 12.10 per cent, and made up the quota of vegetable food. None of them was eaten to a sufficient extent to be of any economic interest.

The following fruits were found in the stomachs:

Blackberry or raspberry (Rubus sp.).

Poison oak (Rhus diversiloba).

Elderberry (Sambucus glauca).

Summary.-In its animal food the Nuttall woodpecker is beyond criticism. Practically all of the insects eaten are either pests or of no positive benefit. While some fruit is eaten, it consists largely, and perhaps entirely, of wild varieties. Probably the worst that can be said of the bird is that it helps in the distribution of poisonoak seeds. ${ }^{1}$

\section{THREE-TOED WOODPECKERS.}

(Picoides arcticus and P. americanus.)

The three-toed woodpeckers are residents of the Boreal zones of North America, in Alaska, Canada, the northeastern United States, and in the mountains of the Western States, south to southern New Mexico and to central California. The two species, including the two subspecies of americanus, are so similar in habits that they may be treated together. All are residents of coniferous forests, from which they sometimes wander a short distance in winter. The trunks of scaly-barked conifers, such as spruces, hemlocks, tamaracks, and lodgepole pines, are their favorite hunting grounds, and here they excavate burrows in which they rear their young and find shelter at night.

In their choice of food these two species are as closely allied as in other respects. The great bulk consists of the larvæ of wood-boring beetles or moths. These are eaten with great regularity throughout the year, but somewhat more in the colder months than in summer. In the dead of winter, when all insect life is apparently quiescent, these birds still obtain their daily food. Flies and bees no longer sport in the sunshine; butterflies and flowers are replaced by sleet and snow; the beetles are either dead or snugly ensconced in crevices in the bark, awaiting the return of warmth, while the larvæ repose in their burrows of solid wood, apparently safe from all disturbance. But undaunted by cold and undeterred by hard work, our intrepid little friends tear open the secure retreats in the bark, or chisel into the solid wood, and feast upon the luckless insects.

Unfortunately only 28 stomachs of Picoides arcticus and 23 of $P$ americanus were available for examination. There are few birds

1 Another species of Dryobates ( $D$. arizonæ), of which no stomachs have been received, inhabits the mountains from northeastern Arizona and northwestern New Mexico south into Mexico. 
which eat more of the pests of the forests than do the three-toed woodpeckers; and while we have no doubt determined the principal food factors, there are many minor questions for the solution of which additional material is necessary.

In the first analysis the food divides into 88.69 per cent of animal matter to 11.31 of vegetable for arcticus, and 94.06 per cent of animal to 5.94 of vegetable for americanus. The largest item with both species is wood-boring coleopterous larvæ. These amount to 64.25 per cent with arcticus and 60.66 with americanus. Caterpillars, which in this case are mostly wood-boring species, amount to 12.88 and 14.45 per cent for the two bird respectively. The total of woodboring larvæ, including both caterpillars and beetles, is 77.13 per cent for articus and 75.11 per cent for americanus, or more than three-fourths of the food of each species. Stomachs containing 15 to 20) of these grubs are very common, and one held 34. Probably the stomach is filled several times each day, and it does not seem. unreasinable to assume that a bird will eat 50 of these insects every 24 hours for 6 months and at least 25 daily for the other half of the year. At this rate one bird will annually destroy 13,675 of these destructive grubs. If this assumption be true, the birds of these two species must destroy an immense quantity of wood-boring insects, even if they do not cause any perceptible diminution in their numbers. Beetles other than wood-borers amount to 3.41 per cent for arcticus and 10.39 for americanus. A considerable proportion of these were weevils, including quite a number of engravers (Scolyticlip). They are, however, eaten so irregularly as to indicate that they are taken only incidentally and are not sought, as are the woodboring grubs. Ants constitute 6.35 per cent of the food of areticus and 8.29 of that of americanus. None of these were taken in winter, and most of them were eaten in spring and summer. The Picoides do not belong to the ant-cating group of woodpeckers. A few other insects and spiders amount to less than 1 per cent for each species and make up the remainder of the animal food.

Vegetable food-Vegetable matter constitutes 11.31 per cent of the stomach contents of arcticus and 5.94 per cent of that of americanus. It can all be included in four items: Fruit, mast, cambium, and rubbish. Fruit skins were found in only 1 stomach of americanus and mast in but 1 stomuch of arcticus. Cambium was found in 10 stomachs of arcticus and 8 of americanus. This indicates that these birds do some pecking at the bark of living trees for other purposes than getting insects, but no complaints have yet been made, from which we infer that little or no damage is done; in fact the amount contained in the stomachs is not large, a little less than 10 per cent. Rubbish, consisting principally of rotten wood, was found in 9 
stomachs. Where a bird pecks wood as much as do these, it is no wonder that some of it is swallowed with the grubs that are embedded therein.

Summary.-The foregoing discussion of the food of the two species of Picoides shows that these birds act as "conservators of the forest" in the strongest sense. Three-fourths of their food consists of the direst enemies of forest trees. In the Report on Forest Insects by the United States Entomological Commission, some 25 species of cerambycid and buprestid beetles are noted as preying upon the ash tree and 35 upon the pine. Since the family Cerambycidæ contains upward of 7,500 species, of which 600 are found in America, since all pass their larval stage within the substance of some tree or woody plant, and since many remain in the larval state two or three years, evidently they inflict upon forest trees and other plants an immense amount of damage. Probably there are not many other agencies more destructive to timber than this family of beetles. Nor is timber safe even after it has been cut. Logs lying in the mill yard or forest may be ruined in a single season if these creatures are not prevented from depositing their eggs. So long do some of these larvæ live in the wood that they sometimes emerge after it has been converted into furniture and passed into household use. A very efficient check upon the undue increase of these insects is found in the woodpeckers, especially the two species of Picoides. In orchards, or in parks, it may be easy to combat insect enemies by insecticides or other artificial means, but in the forest this is more difficult and expensive, and it behooves the forester to take advantage of all helpers which Nature has provided; among these, insectivorous birds must take high rank. It is unfortunate that in most places three-toed woodpeckers are not as numerous as many other species, and for this reason they should be protected and encouraged in every possible way.

YELLOW-BELLIED WOODPECKER OR SAPSUCKER.

(Sphyrapicus varius and subsp.)

The yellow-bellied woodpecker or sapsucker (Pl. II) is probably the most migratory of all our woodpeckers. It breeds throughout the whole of southern Canada from ocean to ocean and thence southward to northeastern California, western Texas, northern Missouri, northern Ohio, and Massachusetts, and in the mountains south to North Carolina. It winters from near the southern limit of the breeding range south to Mexico, Cuba, and Costa Rica.

It is to this species that the term sapsucker is most often and most justly applied, for it drills holes in the bark of certain trees and drinks the sap. It feeds also on cambium, insects, and wild fruits and berries. 
In writing of the habits of these woodpeckers in northern New York, in 1878, Dr. Merriam states:

They really do considerable mischief by drilling holes in the bark of apple, thornapple, and mountain ash trees in such a way as to form girdles of punctures, sometimes 2 feet or more in breadth (up and down), about the trunks and branches. * * * The holes, which are sometimes merely single punctures, and sometimes squarish spaces (multiple punctures) nearly half an inch across, are placed so near together that not infrequently they cover more of the tree than the remaining bark. Hence, more than half of the bark is sometimes removed from the girdled portions, and the balance often dries up and comes off. Therefore it is not surprising that trees which have been extensively girdled generally die, and mountain ash are much more prone to do so than either apple or thornapple trees, due, very likely, to their more slender stems. ${ }^{1}$

The late Frank Bolles has published some interesting detailed observations respecting the food habits of the sapsucker. His conclusions are:

That the yellow-bellied woodpecker is in the habit for successive years of drilling the canoe birch, red maple, red oak, white ash, and probably other trees, for the purpose of taking from them the elaborated sap, and in some cases parts of the cambium layer; that the birds consume the sap in large quantities for its own sake and not for insect matter which such sap may chance occasionally to contain; that the sap attracts many insects of various species, a few of which form a considerable part of the food of this bird, but whose capture does not occupy its time to anything like the extent to which sap drinking occupies it; * * * that the forest trees attacked by them generally die, possibly in the second or third year of use. ${ }^{2}$

Mr. Bolles shot 8 sapsuckers in July and August, 1890. Their stomachs "were well filled with insects." Some of these were examined by Mr. Samuel H. Scudder, who states:

The insects in the different stomachs are in all cases almost exclusively composed of the harder chitinous parts of ants. In a cursory examination I find little else, though one or two beetles are represented, and No. 4 must have swallowed an entire wasp of the largest size, his head and wings attesting thereto. ${ }^{3}$

Mr. Bolles proved by experiment that concentrated sap (saturated with sugar) is not sufficient to sustain life, even with the addition of a small percentage of insects. The logical inference is that sap, while liked by the birds and consumed in large quantities, holds a subordinate place as an article of food.

J. Maurice Thompson says of the sapsucker:

Its food is sap or juices of green trees. It eats nothing else. $* * *$ The principal trees from which it obtains its food are the maples, hickories, cedar, apple, pear, southern pine, and swamp ash. ${ }^{4}$

In speaking of this species Dr. Hopkins mentions the finding of a small pitch pine tree that had recently died from injuries by woodpeckers. The birl evidently attacks the healthy tree for the sole

\footnotetext{
1 Bull. Nuttall Ornith. Club, IV, 3-5, January, 1879.

2 A uk, \III, 270, July, 1891.

s Auk, VIII, 269, July, 1891.

4 Appleton's Journal, VIII, 631, Dec. 7, 1872.
} 
purpose of feeding on the inner bark. Thus, instead of destroying insects, it made the conditions favorable for the attack of bark beetles and other insects which had bred in the bark and wood in considerable numbers. To anticipate the possible conclusion that the woodpecker intended to thus trap the insects and return to eat them, Dr. Hopkins added that at the time the observations were made, the insects had not been molested. ${ }^{1}$

This investigation of the food-of the yellow-bellied sapsucker is based upon examination of the contents of 313 stomachs, collected in 24 States, Canada, and the District of Columbia, and distributed over 12 months of the year. Of this food 49.31 per cent is animal matter and 50.69 vegetable. This is the first species discussed in which the vegetable part of the diet is greater than the animal. This is true of 5 of the 16 species under consideration.

Animal food.-Useful beetles, i. e., predaceous ground beetles and ladybirds (Coccinellidæ), are eaten by the sapsucker to the extent of only 0.91 per cent of the whole food. Other beetles amount to 4.54 per cent, and are made up of weevils, dung beetles (Aphodius), and click beetles, with a few cerambycid larvæ. Ants amount to 34.31 per cent of the whole food, or 69 per cent of the animal part. They are evidently favorite food, being eaten quite regularly through the year, although the months from May to August, inclusive, show the highest percentages, averaging over 68 per cent. Other Hymenoptera amount to 2.64 per cent, and are very irregularly taken. October appears to be the month of greatest consumption, with 15.07 per cent. Hemiptera are eaten very sparingly. Scales (Coccidæ) were found in two stomachs, and in one were identified as the plum scale (Eulecanium cerasifex); these, with a few stink bugs, amount to a little less than 1 per cent for the year. A few miscellaneous insects and spiders aggregate 5.44 per cent. The insects consist of May flies, stone flies, grasshoppers, crickets, tree hoppers, caterpillars and moths, and flies (Diptera). A few eggs were found, probably those of the tent caterpillars (Malacosoma).

The following is a list of inseets identified in the stomachs: COLEOPTERA.

Coccinella 9 -notata. Coccinella sanguinea. Adalia bipunctata.

Anatis sp.

Læmophlæus biguttatus.

Onthophagus sp. Aphodius fimetarius.
Aphodius inquinatus.

Dichelonycha sp.

Xanthonia 10-notata.

Diabrotica 12-punctata.

Canifa pallipes.

Pandeletejus hilaris.

Balaninus sp.

HYMENOPTERA.

Vespa maculata.

Pimpla sp.

Vespa arenaria. 
HEMIPTERA.

Plum or cherry scale (Eulecanium cerasifex).

LEPIDOPTERA.

Tent caterpillar (Malacosoma sp.).

Tegetable food.-The two principal items of vegetable food are fruit and cambium. Twenty-two species of wild fruit and two of cultirated were identified. In general the least fruit is eaten in spring and summer and the most in fall and winter. Altogether it was found in 118 stomachs, none in May and the most, 71.26 per cent, in November. It was evidently mainly berries left on the bushes. Seeds of Rubus fruit, which may be either wild or cultivated, were found in two stomachs, and two contained what was thought to be apple pulp. The total of the fruit is 28.06 per cent of the food, but eridently has little economic interest. The apple was probably the only cultivated variety and this was eaten only twice. Cambium, or the inner bark of trees, was eaten erery month, but mostl 5 in winter and spring. The greatest consumption is in April, 4\$.95 per cent, and the least in November, 1.53 per cent. It was found in 1.27 stomachs and was the entire contents of 1:. The average for the year is $16.5 t$ per cent, which is exceeded by only two itens-fruit and ants. The subjects of cambium and sap sucking hare been discussed on a previous page. Irast, poison Rhus seeds, mullein, and rubbish collectirely make up the remaining 6.09 per cent. Mast was found in 15 stomachs, and is eridently not specially sought. Poison iry seed was contained in seren stomachs and poison sumac in one, so the sapsucker does little harm by distributing the seed of these noxious plants. Rubbish was found in 48 stomachs. It was mostly bits of the outer bark of trees, evidently swallowed when pecking for cambium.

The following fruits and seeds were found in the food:

Red cedar (Juniperus virginiana).

Greenbrier (Smilax sp.).

Hackberry (C'ltis occidentalis).

Sassafriss (Sassafras sassafras).

Blackberry or raspberry (Rubus sp.).

Shad or service berry (Amelanchier canadensis).

Choke cherry (Prunus virginiana).

Black cherry (Prunus serotina).

Poison sumac (Rhus vernix).

Poison ivy (Rhus radicans).

American holly (Ilex opaca).

Ink berry (Ilex glabra).

Swamp holly (Ilex decidua).
Black alder (Ilex verticillata).

Burning bush (Euonymus americanus).

Frost grape (Titis cordifolia).

Virginia creeper (Parthenocissus quinquefolia).

Flowering dogwood (Cornus florida).

Sour gum ( Iyssa sylratica).

Blueberry (Vaccinium sp.).

Black nightshade (Solanum nigrum).

Mullein (T'erbascum thapsus).

Red-berried elder (Sambucus pubens).

Elder (Sambucus sp.).

Poke berry (Phytolacca decandra).

Summary.-In the animal food of the yellow-bellied sapsucker, ants are the most important item, and while of no great economic 
interest they must be reckoned in the bird's favor. On the other hand, the damage this sapsucker inflicts in eating the cambium and sap of trees is so serious that it more than counterbalances any good that the bird does in other directions. Investigations show that the damage to timber, especially in the Soutbern States, is extensive and serious. ${ }^{1}$

\section{RED-BREASTED SAPSUCKER.}

(Sphyrapicus ruber and subsp.)

The red-breasted sapsucker is confined to the Pacific coast region, and ranges from central Lower California in winter, north in summer through California, Oregon, and Washington to Alaska. Naturally it seems to be a forest bird, but it takes kindly to orchards and ranches. It is migratory to a slight extent, but summers as far south as the San Bernardino Mountains. It makes, however, a minor migration in many localities by descending the mountains to the valleys, in which it winters.

Speaking guardedly of this bird, Maj. Charles Bendire says:

I am inclined to think that this species does not indulge in the habit of girdling trees for the sap and the soft inner bark (cambium) to the same extent that Sphyrapicus varius does; at any rate, not during the breeding season. ${ }^{2}$

On the other hand, Prof. Cook, of Claremont, California, gives the following direct testimony:

Sphyrapicus ruber is the sapsucker of southern California. It taps fruit trees, especially prune and apricot, and evergreens. Its mischief seems much more serious than that of its congener of the East, as trees are frequently killed by reason of its punctures, although these latter are more distant and less numerous. I never knew a tree to be killed by the sapsuckers in Michigan. The evil in California is wrought in summer, when the dry season has enfeebled the tree, and this is a possible explanation of the more serious harm to the trees of this region. ${ }^{3}$

In the face of this conflicting testimony we may infer that the habits of the bird vary with the locality.

In Oregon the writer observed trees of white birch and mountain ash growing in a village yard which were badly injured by this bird.

Only 34 stomachs of this species were available for examination, and none were taken in the months from April to August, inclusive, while 29, or five-sixths of all, were collected in October, November, and December. Only some general ideas of the food can be expected from so little material.

In the first analysis we find practically 69 per cent of animal food to 31 of vegetable.

Animal food.-This species is a much greater insect eater than $S$. varius. Ants, the largest item, amount to 42.49 per cent. They

\footnotetext{
1 A bulletin upon this subject is in preparation by W. L. McAtee.

2 Bendire, Maj. Charles, Life Histories of North American Birds, II, 94, 1895.

a Cook, A. J., Auk, XIII, 85, 1896.
} 
were eaten freely in every month in which stomachs were taken except February, and 4 stomachs contained nothing else. Other Hymenoptera aggregate a little more than 7 per cent. Beetles of all kinds amount to only 4 per cent, and none of them are of useful species. The greater number belong to the family Chrysomelidæ, or leuf-eaters. Diachus auratus was the only one identified. One stomach contained the remains of Rhinosimus pallipes, a member of the Pythidæ, a small and rather rare family. Caterpillars were found in 2 stomachs, locust eggs in 1 , and a caterpillar formed the entire contents of 1 . All these amount to 15 per cent, and make up the rest of the animal food.

Vegetable food.-Of the vegetable food, fruit constitutes 12.69 per cent. Berries of the pepper tree (Schinus molle) were found in 3 stomachs, cascara (Rhamnus californicus) in 1, pulp not further identified in 3, and figs in 1 . Only the last is of any economic importance. Seeds of poison oak were found in 4 stomachs, wax myrtle (.Mrica californica) in 1, and unidentified seeds in 1 . Seerls altogether amount to 5.96 per cent. Cambium was found in only 6 stomachs, but nggregated 11.13 per cent, which is three-fourths as much as was eaten by S. varius. Nearly all that had taken it at all had eaten a good percentage. Stomach examinations alone do not enable us to settle the status of the bird, for which more material and some field observation will be necessary.

Summary.-It appears that the red-breasted sapsucker attacks and injures trees, but whether it is as destructive as its eastern relative is not yet known, and more material and further observations are necessary to settle the question.

\section{WILLIAMSON SAPSUCKER.}

(Sphyrapicus thyroideus.)

The Williamson sapsucker is a bird of mountains and evergreen forests. Its range extends from the eastern slope of the Rocky Mountains westward to the Pacific, and from Arizona and New Mexico northward to British Columbia; south in winter to Mexico. The bird is likely to be of little economic interest except in connection with forests. Only 17 stomachs of this species have been received by the Biological Survey, and all but 2 of these were collected in the months from June to September, inclusive. Conclusions based on the examination of so little material must be considered as only tentative. In the first analysis of the food it divides into 87 per cent of animal matter and 13 of vegetable.

Animal food.- Of the animal food a mere trace was shown of clickbeetles (Elateridæ) and less than 1 per cent of crane flies (Tipulidæ). The remainder, 86 per cent, consists entirely of ants, with which 7 stomachs were entirely filled. This record places this bird at the 


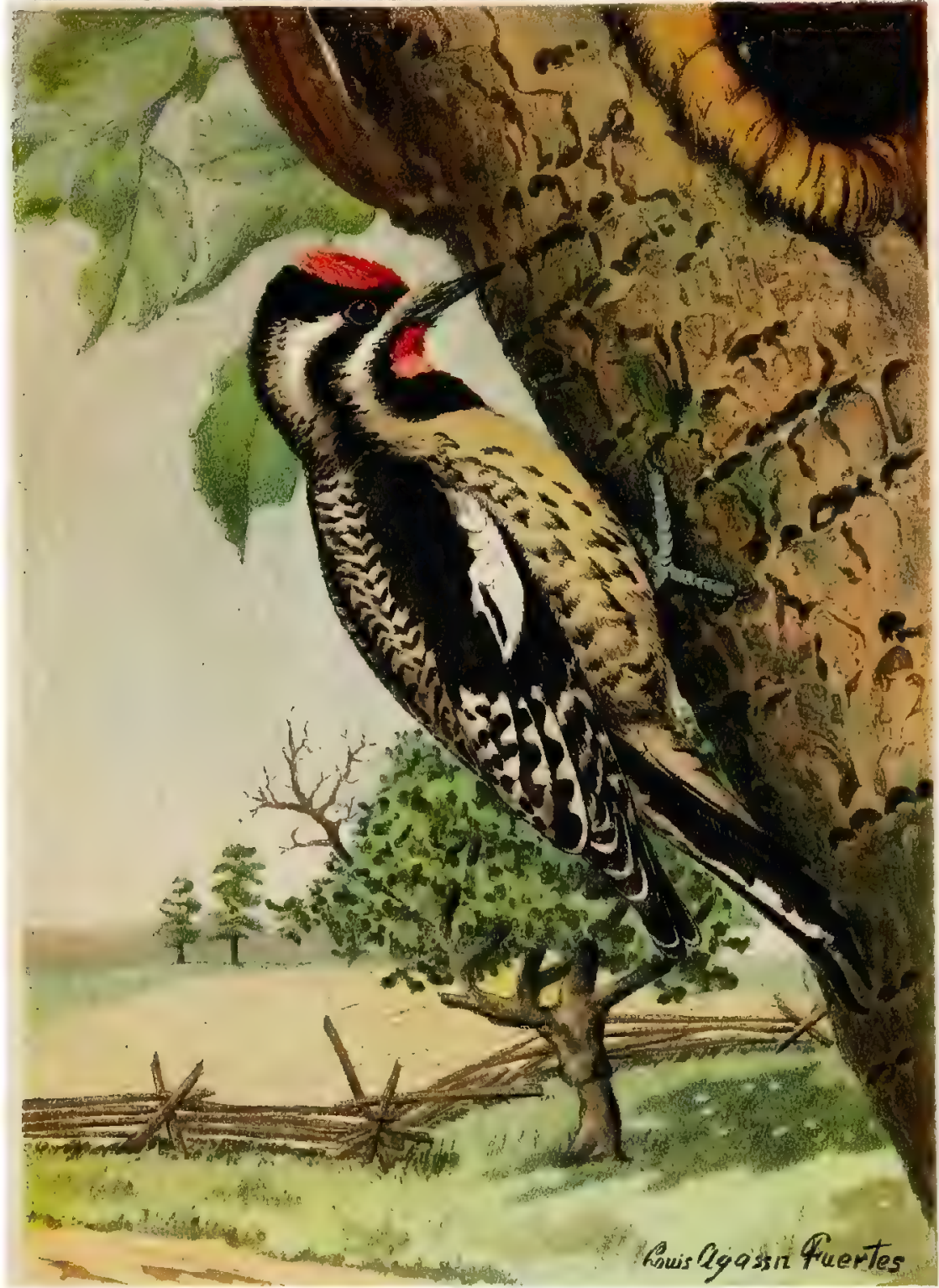





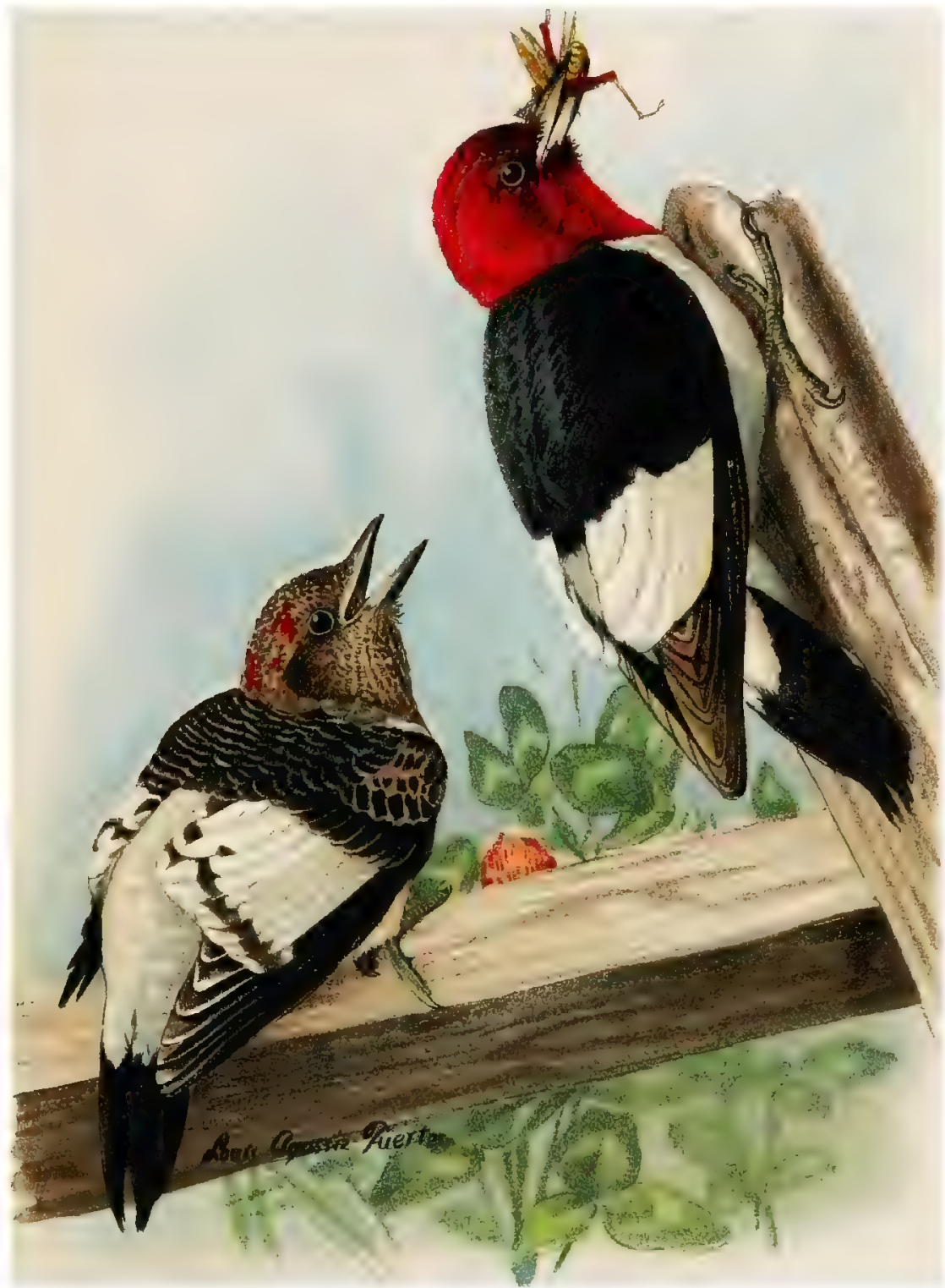

RED-HEADED WOODPECKER (ADULT AND YOUNG). 

head of the woodpeckers in ant eating, but the material is too scanty to warrant final conclusions.

Vegetable food.-Fruit pulp in 1 stomach and rubbish in another, each amounted to less than 1 per cent of the year's food. Cambium occurred in 5 stomachs, and formed the bulk of the vegetable food, 12.55 per cent of the whole.

Summary.-These results would indicate a very limited diet for this bird, but it is altogether probable that a greater number of stomachs would materially modify these figures. They show, however, that the bird eats ants and cambium, if they are not conclusive as to what it does not eat.

\section{PILEATED WOODPECKER.}

\section{(Phlootomus pileatus and subspp.)}

The pileated woodpecker, logcock, woodcock, or cock of the woods, as it is variously called, is the largest member of the family now living in the United States, except the ivory-billed woodpecker, which is very rare. The logcock is essentially a forest bird, and is rarely found except in rather extensive tracts of timber. It is usually shy and retiring, difficult to approach, and better known by its work than by sight. Its large size, loud voice, and habit of hammering upon dead limbs combine to make it a conspicuous inhabitant of the forest. Its strength is wonderful, and it is hard to believe that a bird can so completely destroy a.stump or log. Strips of decayed wood 2 feet long, 4 inches wide, and an inch thick are often torn from a stump and thrown several yards away.

Woodpeckers signal each other by hammering upon a dead and bollow limb or trunk of a tree, or upon the metallic cornice of a building. The pileated is an adept at such telegraphing, and its tattoo on a particularly resonant piece of timber can be heard for more than a mile.

The pileated woodpecker seems to be distributed over the United States in general, and north to Canada, but is absent from some large areas, particularly in the southwestern United States, even where there are extensive forests and other conditions apparently suited to its tastes. It is not migratory in the usual sense, but in winter wanders extensively, usually accompanied by its mate, which leads to the belief that it mates for life.

In the laboratory investigation of this bird's food 80 stomachs were available. They were collected in 14 States, the District of Columbia, and Canada, and are distributed in every month, though May is represented by only 1. The animal food amounts to 72.88 per cent and the vegetable to 27.12. The former consists principally of beetles and ants, and the latter of wild fruits.

75713ํ-Bull. $37-11-3$ 
Animal. food.-Beetles amount to 22.01 per cent. Neally all were in the larval stage, and evidently were dug out of dead and decaying wood. They belong to the Cerambycidre, the Buprestidx, and the Elateridæ, all of them wood-borers, with some Lucanidæ and Scarabæidæ, many species of which breed in rotting timber. Carabidæ, or useful ground-beetles, were found in only 6 stomachs and amount to a small fraction of 1 per cent.

Ants aggregate 39.91 per cent and constitute more than half of the animal food. They were found in 48 stomachs, and in one, 2,600 were counted; in another, 2,080; and in a third, 2,000. They are mostly of the larger species that live in decaying timber. These two items, beetles and ants, make up the bulk of the animal food, 61.92 per cent. It is evident that they are the objects of the bird's search when he is foraging over the trunks of dead trees or logs, and that other insects are taken only incidentally. Flies, caterpillars, fragments of cockroaches and their egg cases (oötheca), bits of grasshoppers, some sawflies, and white ants, no one of which amounts to a respectable percentage, aggregate 10.96 per cent, the balance of the animal food.

The following is a list of insects identified in the stomachs:

COLEOPTERA.

Anisodactylus sp.

Upis ceramboides.

Allorhina nitida.

Chalcophora sp.

Cyclocephala sp.

HYMENOPTERA (ANTS).

- Camponotus pennsylvanicus.

Cremastogaster læviuscula.

Camponotus herculeanus.

LEPIDOPTERA.

Caterpillar (Scolecocampa liburna).

Vegetable food.-The largest item of vegetable food, and in fact the only one of importance, is wild fruit, which amounts to 22.56 per cent, and of which 19 species were identified. This is probably eaten in every month, but in the stomachs examined none was found in April, May, or June; but as only 6 stomachs were collected in those months, the record is not conclusive. The only part of the fruit which can possibly have any economic interest is some Rubus seeds found in 1 stomach and some unidentified seeds in 5 , but probably these were wild like the others. Seeds of poison ivy (or poison oak), poison sumac, dwarf sumac, a little cambium, and mast, with some rubbish, altogether amount to 4.56 per cent and complete the vegetable food.

The following vegetable food was found in the stomachs: 
Greenbrier (Smilax glauca).

Cat brier (Smilax rotundifolia).

Laurel-leaved greenbrier (Smilax laurifolia).

Hackberry (Celtis occidentalis).

Sassafras berry (Sassafras sassafras).

Blackberry or raspberry (Rubus $\mathrm{sp}$.).

Dwarf sumac (Rhus copallina).

Poison sumac (Rhus vernix).

Poïson ivy (Rhus radicans).

American holly (Ilex opaca).

Dahoon holly (Ilex cassine).
Frost grape (Titis cordifolia).

Woodbine (Parthenocissus quinquefolia).

Flowering dogwood (Cornus florida).

Rough-leaved dogwood (Cornus asperifolia).

Sour gum (Nyssa sylvatica).

Tupelo gum (Nyssa aquatica).

Persimmon (Diospyros virginiana).

Fringe tree (Chionanthus virginica).

Elderberry (Sambucus canadensis).

Larger withe-rod (Viburnum nudum).

Black haw (Viburnum prunifolium).

Summary.-The food of the pileated woodpecker does not interest the farmer or horticulturist, for it is obtained entirely from the forest or the wild copses on its edge. This bird does not visit either the orchard or the grain field, and all its work in the forest helps to conserve the timber. Unfortunately the bird is so scarce in many places that it is an object of curiosity, and the man or boy with a gun never lets pass a chance to shoot one, although its flesh is unfit for food. In fall and winter it may often be seen in the market in Washington, and probably in cities farther south. Maj. Bendire relates that once when short of provisions he attempted to eat one, but found it extremely unpalatable. Its killing should be strictly prohibited at all times.

\section{RED-HEADED WOODPECKER.}

(Melanerpes erythrocephalus.)

The handsome redhead (Pl. III) inhabits suitable localities throughout most of southern Canada and the United States east of the Rocky Mountains, but is rare in New England and northeastward. It is a familiar bird on telegraph poles and fence posts and feeds largely on insects found upon these bare surfaces, but the vegetable matter in its stomach shows that it forages elsewhere also.

Fifty years ago Giraud stated that on Long Island the red-headed woodpecker arrives early in April, and during the spring "subsists chiefly on insects. In summer it frequents fruit trees, ripe cherries and pears seeming to be a favorite repast. In the fall it feeds on berries and acorns, the latter at this season forming a large portion of its food." 1

In its fondness for mast it resembles its relative, the California woodpecker. In the northern part of its range, where the oak is replaced by the beech, the redhead makes the beechnut its principal food. Dr. C. Hart Merriam has given much testimony under this head. ${ }^{2}$ He states that in northern New York, where it is one of the

1 Giraud, J. P., Birds of Long Island, p. 180, 1844.

2 Birds of Connecticut, p. 66, 1877; Bull. Nuttall Ornith. Club, III, 124, 1878; Mammals of the Adirondacks, p. 226, 1884. 
commonest woodpeckers, it subsists almost exelusively on beechnuts during the fall and winter, even picking the green nuts before they are ripe and while the trees are still covered with leaves. He has shown that these woodpeckers invariably remain throughout the winter after good nut yields and migrate whenever the nut crop fails. $\mathrm{He}$ sars: "Gray squirrels, red-headed woodpeckers, and beechnuts were numerous during the winters of $1871-72.1873-74,1875-76,1877-78$, 1879-80, 1881-8:, 1883-84, while during the alternate years the squirrels and nuts were scarce and the woodpeckers altogether absent;"' and adds that in Lewis County, $\mathrm{X}$. Y., "a good squirrel tear is synonymous with a good year for Melanerpes, and vice versa." In early spring following a nut year, when the melting snow uncovers the ground, they feed on the beechnuts that were buried during the winter. On April 5, 1878, at Locust Grove, N. Y., he shot 6 whose gizzards contained beechnuts and nothing else.

In as interesting article in the Auk, ${ }^{1}$ Mr. O. P. Hay says that in central Indiana during a good beechnut year, from the time the nuts began to ripen, the redheads were almost constantly on the wing, passing from the beeches to some place of deposit. They hid the nuts in almost every conceivable situation. Many were placed in cavities in partly decayed trees; and the felling of an old beech was certain to provide a feast for the children. Large handfuls were taken from a single knot hole. They were often found under a patch of raised bark, and single nuts were driren into cracks in the bark. Others were thrust into cracks in gateposts; and a favorite place of deposit was behind long slivers on fence posts. In a few cases grains of corn were mixed with beechnuts. Nuts were often driven into cracks in the ends of railroad ties, and the birds were often seen on the roofs of houses pounding nuts into the crevices between the shingles. In several instances the space formed by a board springing away from a fence was nearly filled with nuts, and afterwards pieces of bark and wood were brought and driven over the nuts as if to hide them from poachers.

In summer Dr. Merriam has seen the redheads "make frequent sallies into the air after passing insects, which were almost invariably secured." He has also seen them catch grasshoppers on the ground in a pasture.

Dr. A. K. Fisher saw several red-headed woodpeckers feeding on grasshoppers in the streets at Miles City, Mont., in the latter part of July, 1893. Several of the birds were seen capturing these insects near the hotel throughout the greater part of the forenoon. From a regular perch on top of a telegraph pole or cottonwood they descended on their prey, sometimes eating them on the ground, but more often returning to their former post to devour them. 
The following interesting observation was made by Dr. G. S. Agersborg, of Vermilion, S. Dak.: $:^{1}$

Last spring, in opening a good many birds of this species with the object of ascertaining their principal food, I found in their stomachs nothing but young grasshoppers. One of them, which had its headquarters near my house, was observed making frequent visits to an old oak post, and on examining it I found a large crack where the woodpecker had inserted about 100 grasshoppers of all sizes (for future use, as later observation proved), which were put in without killing them, but they were so firmly wedged in the crack that they in vain tried to get free. I told this to a couple of farmers, and found that they had also seen the same thing, and showed me posts which were used. for the same purpose. Later in the season the woodpecker whose station was near my house commenced to use his stores, and to-day (February 10) there are only a few shriveled-up grasshoppers left.

The late Mr. Charles Aldrich, of Webster City, Iowa, states that he saw a red-headed woodpecker catching grasshoppers on the prairie half a mile from timber. In Nebraska grasshoppers were found in 4 out of 6 stomachs examined by Prof. Samuel Aughey.

Besides taking fruit and grain, this woodpecker has been accused of destroying the eggs of other birds and even of killing the young; and from Florida comes a report that it enters poultry houses and sucks the eggs of domestic fowls. Mr. Charles Aldrich, of Webster City, Iowa, suys that a red-headed woodpecker was seen to kill a duckling with a single blow on the head, and then to peck out and eat the brains. ${ }^{2}$ In view of such testimony, remains of eggs and young birds were carefully looked for in the stomachs examined, but pieces of eggshell were found in only 4.

A very unusual trait has been recorded by Dr. Howard Jones, of Circleville, Ohio. He has seen the red-headed woodpecker steal the eggs of eaves swallows, and in cases where the necks of the nests were so long that the eggs were out of reach, the woodpecker made a hole in the walls of the nest and so obtained the contents. In a colony of swallows containing dozens of nests, not a single brood of young was raised. One of the woodpeckers also began to prey upon hens' eggs, and was finally captured in the act of robbing the nest of a sitting hen. ${ }^{3}$

The redhead has been accused of doing considerable damage to fruit and grain, and both charges are fairly well sustained. In northern New York Dr. Merriam has seen it peck into apples on the tree, and has several times seen it feed on chokecherries (Prunus virginiana).

Mr. August Jahn, of Pope County, Ark., writes that it has damaged his corn to the amount of $\$ 10$ or $\$ 15$, and Dr. J. R. Mathers, of Upshur County, IV. Va., says that the same species feeds on cherries, strawberries, raspberries, and blackberries, and that its depredations are

a Ornithologist and Oologist, VIII, 56, 1883. 
sometimes serious. According to MIr. Witmer Stone, of Germantown, $\mathrm{Pa}$, red-headed woodpeckers have been observed to strip a blackberry patch of all of its fruit. Mr. W. B. McDaniel, of Decatur County, Ga., also reports that the sapsucker and redhead eat grapes and cherries, the loss being sometimes considerable. These examples show the nature of the testimony contributed by eyewitnesses, the accuracy of whose observations there is no reason to doubt. That the stomach examinations do not reveal more damaging evidence against the species is not surprising, for a person seeing a bird eating his choice fruit, or in some other way inflicting damage, is more impressed by it than by the sight of a hundred of the same species quietly pursuing their ordinary vocations. Thus an occasional act is taken as a characteristic habit.

In the food investigation of the redhead 443 stomachs were examined. They were collected in 27 States, the District of Columbia, and Canada, and represent every month, though fewer were taken in the colder season, as the bird is inclined to migrate, and remains in the north only when an abundance of food is assured. Of the stomach's contents, animal matter amounts to 33.83 per cent and vegetable to 66.17 .

Animal food.-Beetles amount to about 19 per cent of the food. Of these, 7.34 per cent consist of predaceous ground beetles and tiger beetles, with a few ladybird beetles, all of which are useful. This is the highest percentage of useful insects eaten by any of the woodpeckers. Among the species taken are the fire ground-beetle (Calosoma calidum) and the searcher (C. scrutator), both predaceous species of large size and vile odor.

Passalus cornutus, one of the staghorns, a large species, was also found, as well as a pair of mandibles belonging to Prionus imbricornis, one of the largest species in the United States. The remainder of the beetle food is made up of various families, of which the May beetles (Scarabæidæ) are the most prominent. They amount to 6.31 per cent and are mostly flower-beetles (Euphoria) or closely allied genera. A preference for large beetles is a pronounced characteristic of this woodpecker. Weevils were found in 99 stomachs and as many as 12 were counted in one. Such harmful species as Epicxrus imbricatus, Phytonomus punctatus, and Sphenophorus zeæ were identified in several stomachs. The beetles eaten by the redhead are mostly adults, and such species as creep over the bark of trees or on bare fences or telegraph poles, where the bird loves to forage. Unlike the hairy, downy, and three-toed woodpeckers, the redhead eats very few beetle larvæ or other grubs, or ants that live in wood or other places of concealment. Apparently it is not so fond of pecking wood as are the other species, but on the other hand it has been known to peck holes in telegraph and telephone poles 
until they were so weakened as to break down, thereby causing "considerable damage." 1

Ants amount to 5.17 per cent of the food of the redhead, which is the lowest record but one of all the woodpeckers. The greatest number are eaten in June and July, when they aggregate a little more than 14 per cent in each month. As they are mostly taken in the warmer months, it is almost certain that they are captured in the open, not dug out of decaying trees or logs. Hymenoptera other than ants amount to 1.63 per cent. These are of course bees and wasps, and, as this bird is quite skillful in catching insects upon the wing, probably it takes most of them in the air. ${ }^{2}$ In one stomach was found one worker honey bee. Parasitic species were identified in a few stomachs. Like the ants, most of the wasps were taken in midsummer.

Hemiptera, or bugs, are a small but rather regular constituent of the food. They aggregate only 1.89 per cent of the yearly diet, but include some interesting species. A collection of 6 stomachs was received from Ames, Iowa, at a time when a brood of 17-year locusts (Tibicen septendecim) was out. These insects had been eaten by every one of the birds, and they averaged 52 per cent of the stomachs' contents. Field observation, as well as stomach examination, shows that cicadas are eaten in their season by all kinds of insectivorous birds big enough to manage such large insects. Cicadas were found in 10 stomachs, but not all were identified as the 17-year species. Scales (Coccidæ), or bark lice, were found in 17 stomachs, and in 5 they were identified as the plum or cherry scale (Eulecanium cerasifex). In 1 stomach this species amounted to 60 per cent of the contents. This shows that the bird forages to some extent among the smaller branches and twigs of live trees. A few individuals of several other families of bugs were found, of which Pentatomidæ, or stinkbugs, were the favorites.

Orthoptera; in the shape of grasshoppers, crickets, and cockroaches and their eggs, were eaten very sparingly throughout the year; but in August, the grasshopper month, the redhead takes to the ground, where it feeds quite freely upon these insects. They aggregate 21.17 per cent of its diet in August, and in September 9.53 per cent, amounting in the two months to two-thirds of the grasshoppers taken in the year. The average for the year is 3.58 per cent. There is much testimony that many grasshoppers are stored up for future - use. They do not, however, constitute a very large element of the food after September. The redhead may share the instinct

1 Buchler, M. H., Pennsylvania Telephone Co., in letter to Biological Survey, dated Harrisburg, Pa., March 19, 1895.

2 See Merriam, Bull. Nuttall Ornith. Club, III, 126, July, 1878; also Forest and Stream, IX, 451, January $17,1878$. 
of its California cousin and store up much food that it never eats, thus contributing to the welfare of pilferers of the food.

Lepidoptera, that is, caterpillars, are apparently not a favorite food of the redhead. A few were eaten in the months from April to October, inclusive, but in May only do they reach 10 per cent of the food. The average for the year is 1.63 per cent. One harmful species, the wheat-head army worm (Heliophila albilinea), was identified in one stomach, which contained about a dozen specimens. Dragonflies, spiders, and millepeds, bits of a crayfish, eggshells, and a few bits of bone and hair of some small rodent, altogether make up the remaining 1 per cent.

The following insects were iclentified in the stomachs of the redhead:

Cicindela sp.

Carabus sp.

Calosoma scrutator.

Calosoma calidum.

Pasimachus depressus.

Scarites subterraneus.

Pterostichus sayi.

Pterostichus sp.

Amara fulvipes.

Galerita janus.

Chlanius sp.

Geopinus incrassatus.

Agonoderus pallipes.

Anisodactylus discoideus.

Anisodactylus nigrita.

Anisodactylus sp.

Tropisternus sp.

Sphæridium scarabæoides.

Necrophorus sp.

Creophilus villosus.

Staphylinus vulpinus.

Staphylinus maculosus.

Coccinella 9-notata.

I $p$ s fasciatus.

Yelanotus fissitis.

I'assalus cornutus.

Phanzus carnifex.

Canthon laris.

Canthon sp.

Onthophagus sp.

Atrnius cognatus.

A phodius fossor.

Aphodius fimetarius.

Aphodius ruricola

Apis mellifera.

Vespa maculata.
COLEOPTERA、

Aphodius inquinatus.

Aphodius sp.

Bolboceras farctus.

Dichelonycha sp.

Macrodactylus subspinosus.

Lachnosterna sp.

Anomala sp.

Allorhina nitida.

Euphoria fulgida.

Euphoria inda.

Euphoria sepulchralis.

Prionus imbricornis.

Elaphidion sp.

Nodonota tristis.

Gastroidea cyanea.

Melasoma scripta.

Diabrotica 12-punctata.

Eleodes tricostata.

Meracantha contracta.

Corymbites cylindricollis.

Dicerca obscura.

Dicerca sp.

Chrysobothris sp.

Ptinus dubius.

Ceruchus piceus.

Epicauta sp.

Epicarus imbricatus.

Sitones sp.

Phytonomus punctatus.

Hylobius pales.

Balaninus sp.

Sphenophorus zex.

Sphenophorus sp.

HYMENOOPTERA.

Ophion sp.

Camponotus sp. 


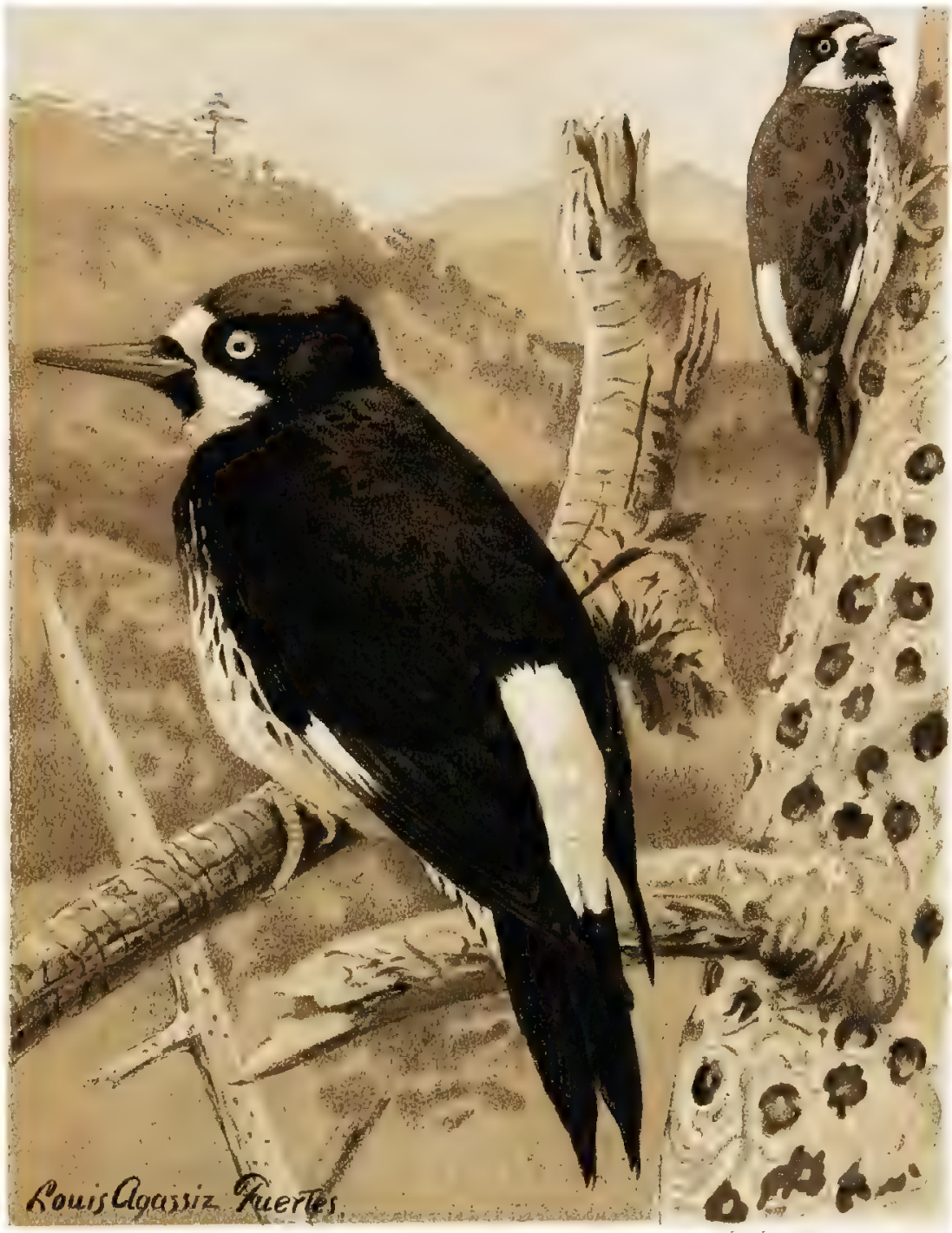





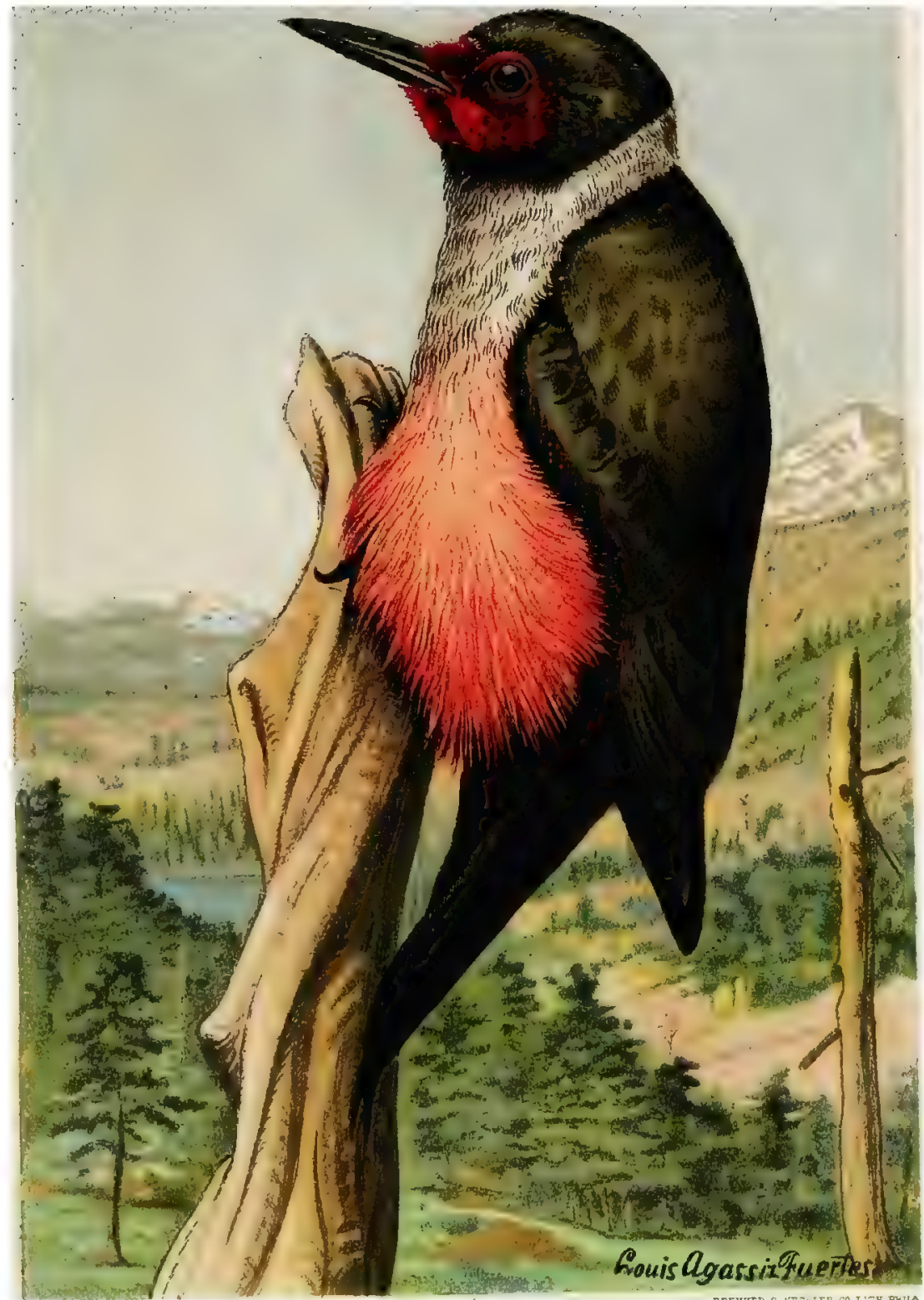



HEMIPTERA.

Nezara hilaris.

Sinea diadema.

Tibicen septendecim.
Tibicen sp.

Eulecanium cerasifex.

LEPIDOPTERA.

Wheat-head army worm (Heliophila albilinea).

Vegetable food.-Some grain is eaten by the redhead from May to September. In August and September it amounts to 21.73 and 19.67 per cent, respectively. The average for the year is 4.25 per cent. Corn was identified in 64 stomachs and oats in 2. The former was in most cases immature or in the milk, and was more or less mixed with corn silk. Domestic fruit was found in 175 stomachs - that is, if the seeds of blackberries and raspberries and the pulp without seeds were all of domesticated varieties. Blackberries and raspberries were identified in 42 stomachs, domestic cherries in 15 , strawberries in 7 , and apples in 9 . Cultivated fruit was all taken in the months from April to September, inclusive, with the maximum of 16.76 per cent in July. The average for the year is 3.30 per cent. The above account undoubtedly does the bird great injustice, as probably most of the Rubus fruit (blackberries and raspberries) was obtained from wayside thickets, and it is almost certain that much of the unidentified pulp contained in 102 stomachs was from wild species. The strawberries also were as likely to be wild as cultivated. Wild fruits were found in 100 stomachs, and 17 species were identified. They were eaten in every month, the most in the colder ones. February appears to be the month of maximum consumption with 50 per cent, but the record is based on only 9 stomachs. The average for the year is 16.90 per cent. Anthers of flowers should perhaps be included in this item. They were found in 4 stomachs.

Mast is evidently a favorite food of the redhead. It appears in the stomachs of every month except March, but as only 3 were taken then the exception is probably accidental. The most was eaten in the four months from October to January, inclusive, and the average for those months is 55.22 per cent, and for the year 23.26 per cent. The great bulk of this is acorns, but some other nuts and large seeds are included. This record for mast eating is, as far as known, exceeded by only a few birds, notably the California woodpecker and the jays.

Miscellaneous vegetable matter amounts to 18.30 per cent. This is made up of cambium, found in 5 stomachs, poison-ivy seeds in 7 , several other Rhus seeds, and a number of weed seeds. The great bulk of this item, however, is a mass of hard woody granules of very irregular shape and undetermined origin. They were found 
in 90 stomachs, and one contained nothing else. They have a resemblance to the woody granules in pear pulp, but are larger and more irregular. It is possible that they are derived from the pulp of some wild fruit. If so, their percentage should be added to the fruit pulp. They have been found in the food of other woodpeckers, but in comparatively small quantities.

The following fruits and seeds were identified:

Bristly greenbrier (Smilax bona-nox).

Mulberry ( Iorus rubra).

Dock (Rumer sp.).

Lambs quarters (Chenopodium album).

Shadbush or service berry (Amelanchier canadensis).

Bird cherry (Prunus pennsylvanica).

Chokecherry (Prunus virginiana).

Black cherry (Prunus serotina).

Dwarf sumac (Rhus copallina).

Smooth sumac (Rhus glabra).

Poison ivy (Rhus radicans).

Fox grape (Vitis vulpina).
Frost grape (Vitis cordifolia).

Woodbine (Parthenocissus quinquefolia).

Flowering dogwood (Cornus florida).

Rough-leaved dogwood (Cornus asperifolia).

Panicled dogwood (Cornus candidissima).

Sour gum (Nyssa sylvatica).

Huckieberry (Gaylussacia sp.).

Black nightshads (Solanum nigrum).

Black elderberry (Sambucus canadensis).

Red elderberry (Sambucus pubens).

Ragweed (Ambrosia sp.).

Summary.-No species of woodpecker in this country, with the possible exception of the yellow-bellied sapsucker (Sphyrapicus varius), has been the subject of so much adverse criticism as the redhead. It has been accused of eating nearly every variety of cultivated fruit from strawberries to oranges, of pecking corn from the ear, of eating the eggs of poultry and pigeons, of pecking open the skulls and devouring the brains of young poultry, and of destroying the eggs or young of eaves swallows and other birds. These accusations are well grounded, but the habits are probably only local. These reports have been received from hundreds of localities, but in thousands of other places where the bird abounds no such acts have been observed. Stomach examination confirms to some extent the corn-eating habit, and to a less degree the fruit-eating, but fails entirely to show that the bird habitually eats young birds or eggs. ${ }^{1}$ Where this bird has done appreciable harm, it has probably been due to new and unusual conditions likely to be temporary. In its animal food the redhead does a little harm theoretically by its destruction of predatory beetles, but the harmful species eaten are enough to balance this. On the whole, there seems to be no reason to condemn this woodpecker except under very unusual conditions, and the man who claims to have killed 527 of them in four years did himself and neighbors a very doubtful service.

\footnotetext{
1 Eggshells have been found in some stomachs of nearly every species of bird yet examined by the writer. They are undoubtedly, in most cases, old shells eaten for the lime.
} 


\section{CALIFORNIA WOODPECKER.}

\section{(Melanerpes formicivorus bairdi.)}

The California woodpecker (Pl. IV) is distributed throughout most of the oak-covered mountain and foothill region of California, northern Lower California, and southern Oregon. It lives generally wherever large oaks are abundant, and from these it gets much of its living. Wherever it occurs it is commonly abundant, and its strongly contrasted colors and loud cries attract much attention as it flies from tree to tree. A peculiar habit has drawn much notice from nonscientific observers - that of drilling holes in tree trunks or large branches, in each of which it places an acorn. Where this bird is abundant all dead trunks or branches of any size, and many live ones, are punctured with these holes, frequently less than an inch apart. So zealous is the bird in this work that often when trees in the proper condition for puncturing are not numerous enough, it attacks buildings and drills holes in the cornices of houses or in the spires of churches; also it bores into telephone and telegraph poles and fence posts, and sometimes uses natural cavities. But the woodpecker does not get the benefit of all the acorns it lays up, for the jays have learned where they can easily obtain food in winter, and are not backward about robbing the woodpecker's larder, thus causing endless quarrels. Probably rats, mice, and squirrels also help themselves to these supplies.

For the laboratory investigation of the food of the California woodpecker 84 stomachs were available. They were taken in every month except February, April, and May - the larger numbers in June and July, when the chances for the bird to do mischief are greatest. The food was found to consist of 22.59 per cent of animal matter to 77.41 per cent of vegetable. This is the highest percentage of vegetable matter yet found in the stomach of any woodpecker, though the red-bellied (Centurus carolinus) comes very close to it. Most other woodpeckers eat more animal than vegetable food.

Animal food.-Beetles constitute the smallest item in the animal food. They amount to less than 3 per cent, and are distributed among several families, with no preference shown for any one. In July, the only month in which they are at all prominent, they reach 14.76 per cent. No wood-boring larvæ were found. This seems to indicate that this bird uses its wood-pecking powers, not to find insects, but only to make places for storing food. Ants amount to 8.09 per cent of the food. In one stomach taken in March they constitute 50 per cent of the contents, but in no other do they reach 11 per cent. The specific name of this bird, formicivorus, is not well chosen, for it eats fewer ants than most other species of woodpeckers. Other Hymenoptera amount to 7.34 per cent. More than half of these 
were contained in stomachs taken in August, when they aggregate 37.33 per cent. A few bugs, flies, and grasshoppers, with some fragments of caterpillars, make up the remainder of the animal food-4.49 per cent. One stomach contained a few black olive scales.

Vegetable food.-Grain, fruit, and mast are the three items that form nearly all the regetable food. One stomach taken in January contained nothing but corn, and in another collected in December were a few corn hulls. This is the whole of the grain record, and is of no economic interest. The average for the year but slightly exceeds 1 per cent. Fruit amounts to a little less than 23 per cent, and was found in nearly every month in which stomachs were taken. Most of it was evidently the pulp of the larger cultivated varieties, though that found in stomachs collected in the winter months could have no economic value. Seeds of the elderberry (Sambucus) were found in two stomachs and were the only fruit positively identified. The largest amounts were eaten in August and September, when they reached 59.34 and 54 per cent, respectively. While this is rather a high percentage of fruit eaten, complaints against the bird are not general, and the damage done to fruit over most of its range is probably comparatively small.

The principal item of the food of the California woodpecker is acorns. This amounts to 53.30 per cent of the food of the year, and was found in 58 stomachs, or 69 per cent of the whole, and 23 contained nothing else. It was eaten in every month when stomachs were taken except August, but as only 3 were collected in that month the record is not reliable. In November, when 12 stomachs were taken, acorns amounted to 93.58 per cent of the average contents. In June, when fruit and insects are abundant, it averaged in 12 stomachs 79.25 per cent. In July the least was eaten-29.47 per cent. This was made up by the animal food, which attained the highest percentage in that month. The question has been raised whether the bird stores the acorn for the sake of its meat or for the grubs which may frequently develop therein. The examination of the stomach contents removes all doubt, for while acorns are eaten freely larvæ are almost entirely wanting.

In certain localities where almonds are largely cultivated and this bird is abundant it exhibits a strong liking for these nuts. Under these conditions it is sometimes necessary to shoot every woodpecker that appears in the orchard in order to save even a reasonable part of the crop. Such conditions are likely to occur wherever large groves of oaks occur in close proximity to the orchards and this bird is correspondingly numerous. While the necessity for applying so drastic a remedy is unfortunate, it can be said that it is not so deplorable as it would be in the case of some other more conspicuously useful species. 
Summary.-The foregoing discussion shows that the food of the California woodpecker is not of much economic importance. On the other hand, the bird can not be charged with destroying useful insects or many products of husbandry. While it eats considerable fruit, especially almonds, in fact twice as much as the linnet, it does not habitually infest orchards, and in most localities is not numerous enough to be a serious nuisance. The few insects which it takes are nearly all of harmful species, while the acorns which make up the bulk of its diet may be considered of little value. The trees used for storehouses are usually either dead or partly so, and when alive are little harmed by the punctures, which do not usually go through the bark. When, however, holes are made in buildings, telegraph or telephone poles, or fences, they are a real injury, and it is fortunate that such cases are local and exceptional. From the esthetic point of view, however, a strong plea for the bird's protection may be made. It is an interesting and picturesque species, and where it does not make itself conspicuous by reason of the damage it does it may well be allowed to live. ${ }^{1}$

\section{LEWIS WOODPECKER.}

(Asyndesmus lewisi.)

The Lewis woodpecker ( $\left.\mathrm{Pl} . \mathrm{V}^{r}\right)$ is irregularly distributed over that part of the United States west of the eastern slope of the Rocky Mountains, north to southwestern Canada, and south to northern Mexico. In many localities within its range it is rare or absent, while very abundant in others. It is by nature somewhat shy, not greatly addicted to visiting orchards and cultivated areas.

In Oregon and Washington complaint has been made that the bird does some damage to apples. Only twice was the writer able to find cases of serious damage. An orchard situated close to a river, on the far side of which was a large area of wild land, was so persistently visited by Lewis woodpeckers, when the early apples were ripening, that the pickers were obliged to shoot the birds. One evening a number of boxes filled ready for market were left in the orchard. In the morning it was found that the woodpeckers had pulled out the papers and pecked the fruit so that it was necessary to open and repack several boxes. In the other case the orchard was in the foothills and almost completely surrounded by evergreen forests, from which the birds came and to which they retreated when alarmed.

Dr. Merriam, speaking of Fall River Valley, California, says of this bird: "Common everywhere and eating apples in several of the orchards." Also at Fort Jones: "Evidently eating apples."

\footnotetext{
1 Besides the California form, bairdi, treated of in these pages, there is at least one other, aculeata, with in the limits of the United States. Its range is in the southern Rooky Mountains from central western Texas to northern Arizona. No stomachs of this subspecies have been received, but probably its food habits do not differ from those of the other form.
} 
Messrs. Grant and Ferry, writing from Klamath Hot Springs, Oregon, say: "Abundant in flocks first part of September. Persons with guns stationed in orchards $* * *$ to destroy these birds, kill 25 to 50 of them per day for from one to two weeks."

Mr. J. E. McLellam says they "never come in great numbers unless there is a good crop of mast, when they come in swarms. They hoard similar to the California woodpecker." Quite a number of apple growers interviewed by the writer testified that the bird destroyed some apples, but none of them considered the loss of any importance. As the orchards increase in area, the damage will probably become less.

Mr. W. Otto Emerson, of Haywards, Cal., in a letter to the Biological Survey, dated March 14, 1909, say's of this bird:

Several cases have come under my observation when in the fall months of September and October the California and Lewis woodpeckers have made their appearance in canyon apple orchards and went into them picking open the apples for the colling moth worms they contained, going all over the trees and taking such fruit as had a wormhole in it. In one orchard of about 2 acres in extent at Sunol, this county (Alameda), near the Niles Canyon, I counted 23 bodies of the Lewis woodpeckers and 9 of the California tied up to the limbs by the legs to frighten off the birds. The owner did not seem to know what the woodpeckers were after ** * till I called his attention to the condition of his wormy fruit.

For investigation of this bird's food only 59 stomachs were available. They were collected in five States from Montana and Wyoming westward to the Pacific coast. They are so irregularly distributed over the year as to make systematic study of the food impossible, but we may learn some of the elements which compose it. Animal matter amounts to 37.48 per cent and vegetable to 62.50 per cent.

Animal food.-Predaceous beetles were eaten to the extent of 6.72 per cent, and, as is usually the case, the most appear to have been taken in spring and early summer. They were made up of Carabidx and Coccinellidx (ladybird beetles). Of the former, the genus Pasimachus was recognized, and of the latter, two species, Hippodamia convergens and $H$. 15-maculata, were identified. Other beetles amount to 2.40 per cent and were all eaten in the five months from June to October. Among them were several Meloidæ, or blister beetles, not usually supposed to be very palatable. One specimen of a water beetle (Philhydrus diffusus) was also identified.

There is nothing in the stomachs to indicate that this bird ever digs into wood, decayed or otherwise, in search of beetle larvæ. Ants were eaten most in summer and in April, and June appears to be the month of maximum consumption, while May shows none. The average for the year is 11.87 per cent, but this can not be considered final. Other Hymenoptera reach 11.57 per cent. Hemiptera, or bugs, seem to be taken very sparingly, and those chosen were of the larger species. They amount to 1.36 per cent. Grasshoppers are 
eaten-not many in August, more in July, and most in September, with a trace in October, while the eastern birds eat the most of these insects in August. The average for the year is 3.20 per cent. No caterpillars or Lepidoptera in any form were found in this bird's stomach. A few spiders amount to less than half of 1 per cent.

Vegetable food. - Corn was found in one stomach taken in August, and constituted 62 per cent of its contents, but amounted to only 0.46 per cent of the food of the year. No other grain was found. Pulp and skins of fruit supposed to be of cultivated varieties were noted in March, the three summer months, and October. There is no certainty that all this was cultivated fruit, and in any event that taken in March could hardly have had any economic value. The aggregate for the year is 10.90 per cent. Wild fruit was identified in 26 stomachs, all of them taken in July, August, and September. In the former it amounted to over 63 per cent of the food, and the average for the year is 14.65 per cent. Six genera-Amelanchier, Mex, Crataegus, Cornus, Prunus, and Sambucus - were identified. Mast, or acorns, is the largest item of food. It was found in 20 stomachs and constitutes 34.46 per cent of the diet. None was found in July, but in all the other months in which stomachs were taken it amounted to a good percentage. The one stomach taken in December contained 75 per cent of this food. Seeds of poison oak (Rhus diversiloba) and a weed (Amaranthus) make up 2.05 per cent, the remainder of the vegetable food.

Summary.-It is hardly possible to draw definite conclusions from so little material, especially when distributed over so large a territory. While the bird eats some useful beetles, probably it does no serious harm in this way. It is not likely to damage grain. Evidently, however, it has a pronounced taste for fruit, which at present is gratified mostly by wild species; but if the wild fruit-bearing shrubs and trees in its range should ever be replaced by cultivated varieties, it would doubtless turn to cultivated fruits. Further investigation in both field and laboratory are necessary in order to fix definitely the economic status of the Lewis woodpecker.

\section{RED-BELLIED WOODPECKER.}

(Centurus carolinus.)

The red-bellied woodpecker ranges over the eastern United States as far west as central Texas and eastern Colorado, and as far north as New York, southern Ontario, southern Michigan, and southern Minnesota. It breeds throughout this range and appears to be irregularly migratory. Very strangely, it often goes north of its breeding range to spend the winter. Four stomachs, collected in November and December, have been received from Canada, and in eight years of residence in central Iowa the writer found the species. 
abundant every year during the winter, but never saw one in the breeding season. It is rather more of a forest bird than some of the other woodpeckers, but is seen frequently in open or thinly timbered country. In the northern part of its range it appears to prefer deciduous growth, but in the south is quite common in pine forests.

There is some evidence that this bird is occasionally injurious to the horticulturist. Dr. B. H. Warren says:

In various sections of Florida, where the red-bellied woodpeskers are exceedingly numerous, in fact by odds the most abundant of all the woodpeckers, the common names of "orange sapsucker" and "orange borer" are universally applied to them. On making inquiry of farmers and others, I learned that the names were given because these woodpeckers "sucked the sap" of orange trees and fed on oranges. Supposing these statements were wrongfully made, I at first gave but little attention to them. When, however, I visited Welaka, Palatka, Volusia, - Deland, and other places where numerous orange trees were thriving, I was informed by the orange growers that the red-bellied woodpeckers oftentimes destroyed large numbers of oranges when they had matured and were ready for picking; also, that "they damaged the orange trees by boring holes in them and sucking the sap." I had but little opportunity of making a careful study of this orange-eating habit, so greatly talked about, owing to the fact that when I first visited these localities it was late in February, or after the oranges had been picked and shipped north. In the month of March, 1885, I camped a few days at Bluffton, near Volusia, in an orange grove owned by Mr. Bird, of New York City. This grove contained about 30 acres of trees, which were loaded with fruit, then being picked for market. Through the kindness of Mr. Bird and his overseer, Mr. Curtis, I collected 26 red-bellied woodpeckers in this orange grove. Eleven of these birds had fed to a more or less extent on oranges.

Three of the 11 stomachs taken from specimens killed in the forenoon, soon after daylight, contained only orange pulp. Eight stomachs showed, in addition to orange pulp, insects and berries. The stomachs of the remaining 15 birds contained no traces of oranges, but revealed chiefly insects, a few berries, and seeds. I examined two dozen or more oranges which had been attacked by the woodpeckers, and found that all had been bored about midway between the stem and blossom end. These holes, always round, varied greatly in size. The birds usually, I think, pick off the skin from a space about the size of an ordinary 5 -cent piece, and then eat out the pulp. In an orchard at Hawkinsville, near Deland Landing, on the St. Johns River, I oftentimes, in the month of A pril, 1885, found oranges which had been evidently overlooked when the crop was gathered, and in most instances observed that they were bored. In this orchard on one occasion I saw a red-bellied woodpecker eating an orange. He evidently recognized the fact that it was about the last of the season, as he had enlarged the opening sufficiently so that his head was almost entirely hidden in the yellow skin, from the sides of which he picked the few remaining particles of pulp. I was shown orange trees that these "sapsuckers" were said to have bored. These borings, however, did not appear to injure the trees, as they seemed to me to be equally as flourishing as other trees whose trunks showed no marks of a woodpecker's bill.

Mr. William Brewster has made some observations on this point. He says:

As corroborating Dr. Warren's account ${ }^{+}$in his late report on the birds of Pennsylvania, it may be worth while to state that when at Enterprise, Fla., in February, 1889, I observed a red-bellied woodpecker eating the pulp of a sweet orange. He flew down to the ground and, hopping along rather clumsily, approached an orange, and 


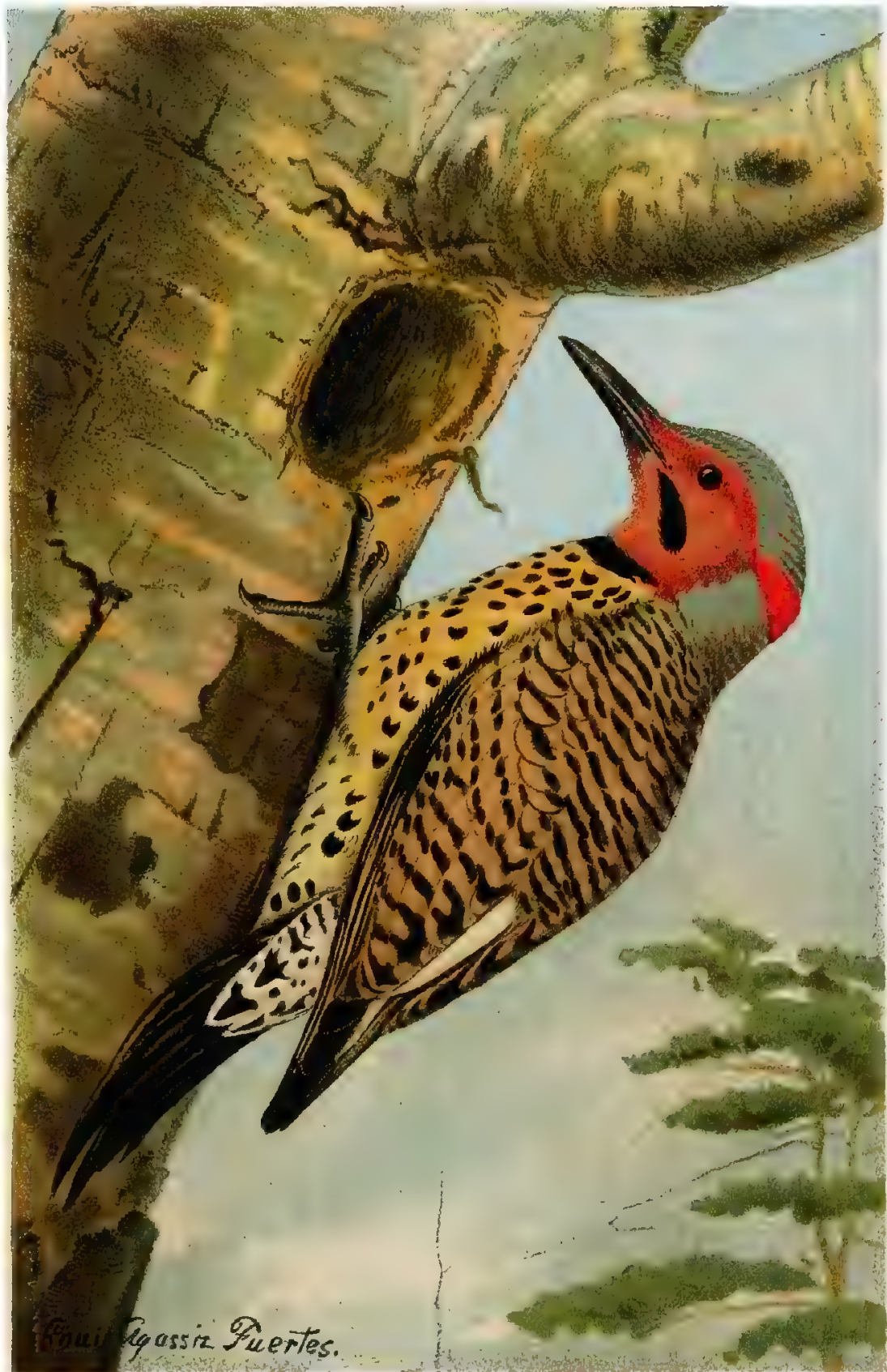

Flicker (Adult Male) 

for several minutes pecked at it in a slow deliberate way. When I showed myseli he at once took flight and sought shelter in the dense foliage of the trees above. Upon examining the orange I found that it was decayed through the whole of one side. In the sound portion were three holes, each nearly as large as a silver dollar, with narrow strips of peel between them. The pulp had been eaten out quite to the middle of the fruit. Small pieces of the rind were thickly strewn about the spot. Upon searching closely I discovered several other oranges that had been attacked in a similar manner. All were partially decayed and were lying on the ground. I was unable to find any on the trees which showed any marks of the woodpecker's bill. The owner of this grove was surprised when I called his attention to the above facts, which were quite new to him. Nor had any of the other orange growers in the neighborhood any knowledge of this orange-eating habit of the red-bellied woodpecker. ${ }^{1}$

Mr. Mortimer also gives testimony upon this habit of the bird:

During February and March, 1889, while gathering fruit or pruning orange trees, I frequently found oranges that had been riddled by this woodpecker and repeatedly saw the bird at work. I never observed it feeding upon fallen oranges. It helped itself freely to sound fruit that still hung on the trees, and in some instances I have found 10 or 12 oranges on one tree that had been tapped by it. Where an orange accidentally rested on a branch in such a way as to make the flower end accessible from above or from a horizontal direction the woodpecker chose that spot, as through it he could reach into all the sections of the fruit, and when this was the case there was but one hole in the orange; but usually there were many holes around it. It appeared that having once commenced on an orange the woodpecker returned to the same one repeatedly, until he had completely consumed the pulp, and then he usually attacked another very near to it. Thus I have found certain clusters in which every orange had been bored, while all the others on the tree were untouched. An old orange grower told me that the "sapsuckers," as he called them, never touch any but very ripe oranges and are troublesome only to such growers as reserve their crops for the late market. He also said that it is only within a very few years that they have shown a taste for the fruit, and I myself observed that, although red-bellies were very common in the neighborhood, only an individual, or perhaps a pair, visited any one grove. In one case a pair took up their station in a dead pine near a grove and made excursions after the fruit at all hours of the day, being easily located by the noise they kept up. ${ }^{2}$

Dr. B. II. Warren states that the stomachs of three red-bellied woodpeckers captured in winter in Chester and Delaware Counties, $\mathrm{Pa}$., contained black beetles, larvæ, fragments of acorns, and a few seeds of wild grapes. The stomachs of eight adults from the St. Johns River, Florida, contained red seeds of two species of palmetto, but no insects. Two additional stomachs from the same locality contained palmetto berries, frogments of crickets (Nemobius and Orocharis saltator), a palmetto ant (Camponotus escuriens), and numerous joints of a myriapod, probably Julus. ${ }^{3}$

Dr. Townend Glover found in the stomach of a red-bellied woodpecker killed in December "pieces of acorns, seeds, and gravel, but no insects. Another, shot in December, contained wing cases of Buprestis,

L Brewster, William, Auk, VI, 337-338, 1889.

2 Mortimer, D. Auk, VII, 339-310, 1890.

3 Birds of Pennsylvania, ed. 2, pp. 174, 178, 1890.

$75713^{\circ}-$-Bull. $37-11-4$ 
and a species of wasp, or Polistes, acorns, seeds, and no bark. A third, shot in May, was filled with seeds, pieces of bark, and insects, among which was an entire Lachnosterna, or Maybug."1

For the inrestigation of the food of the red-bellied woodpecker 271 stomachs were arailable. They were collected in 17 States and Ontario, and represent erers month in the rear, though but few were taken in June and JulY. In the first analysis the food was found to consist of 30.94 per cent animal matter to 69.06 of regetable. The former consists of insects and spiders, with a few tree frogs and lizards, while the latter mar be considered as made up of grain, fruit, and mast.

Animal food.-Predatory beetles (Carabidæ) amount to 0.86 per cent, and consist of some of the larger genera like Pasimachus and Calosoma. Ther were probably found on the bark of trees. Other beetles, all more or less harmful, aggregate-9.32 per cent of the food. Six species of meevils or snout-beetles were identified, and 14 individuals were taken from one stomach. There were also quite a number of wood-boring larræ, which the birds must hare dug out from the wood, thus benefiting the forest. Beetles form a pretty steady article of diet, and starting with 3.62 per cent in January they increase with fair regularity to $\mathrm{MaV}$, when they attain the maximum of 27.57 per cent, from which they slow 5 decrease to 1 per cent in December.

Ants are eaten to the extent of 6.45 per cent of the food and are a fairly constant article of diet. The most are eaten during the warmer months, though none were found in the two stomachs taken in June, which is probably accidental. Evidently this bird does not dig all of the ants it eats from decaring wood, like the downy woodpecker, but, like the flickers, collects them from the ground and the bark of trees. Other Hymenoptera amount to 1.45 per cent, and while these insects are known to be great lovers of warmth and sunshine, most of them are eaten in fall and spring, and many even in winter, when they are usually less numerous. Orthoptera (grasshoppers, crickets, etc.) constitute 5.83 per cent of the food. They Tere found in 51 stomachs-grasshoppers in 27 , eggs of cockroaches in 15, crickets in 8, and a mantis (devil's rear-horse) in 1. Two stomachs contained the eggs of grasshoppers, which indicates that this bird occasionally forages on the ground. Cockroaches were represented entirely by their egg cases (oötheca). These insects extrude their eggs, not singly like most other creatures, but packed together in a case somewhat like the clip of cartridges used for some modern breech-loading rifles. These cases are probably found br birds in crevices of the bark of trees. Orthoptera are eaten throughout the 
year, but in quantities varying greatly from month to month. In a general way, however, more were eaten in the summer season.

Hemiptera, or bugs, amount to 1.86 per cent of the food, and form a small but fairly regular constituent of the monthly diet. Scales were found in one stomach, but most of the bugs eaten were of larger species, and the majority were Pentatomidæ or stink-bugs. Caterpillars were taken quite regularly, and average 2.88 per cent of the diet. A few of them were identified as wood-borers. Spiders and millepeds, with a few doubtful insects and small vertebrates, make up 2.29 per cent, the remainder of the animal food. Spiders were eaten at all times, but in trifling quantities. Small tree frogs were found in 9 stomachs and remains of a lizard (Anolis carolinensis) in 2. One stomach contained the lingual ribbon of a snail.

The following is a list of the insects identified:

COLEOPTERA.

Calosoma wilcoxi.

-Pasimachus depressus.

Pasimachus sp.

Catogenus rufus.

Ips fasciatus.

Trogosita virescens.

Melanotus sp.

Passalus cornutus.

Dichelonycha sp.
Lachnosterna sp.

Nodonota puncticollis.

Hylobius pales.

Lixus sp.

Dorytomus mucidus.

$P$ seudomus truncatus.

Cryptorhynchus obliquus.

Balaninus sp.

Cratoparis lunatus.

HEMTPTERA.

Nezara hilaris.

Vegetable food.-Corn was the only grain found in the food of the red-bellied woodpecker. It was contained in 39 stomachs, rather irregularly distributed through the year, but none in the three summer months, April, or Norember. The great bulk was eaten in the three winter months and in March and September. In September it was undoubtedly from the green ear in the field, but the rest must have been waste. The total for the year is 3.99 per cent. Fruit amounts to 27.28 per cent and forms a notable percentage of the food in every month. The month of greatest consumption is August, with 64.10 per cent, while April shows the least, 7.50 per cent. The larger part of this consists of wild fruit, of which 23 species were identified. What was thought to be apple pulp was found in one stomach, cultivated grape in one, and blackberry or raspberry in one. Fruit pulp not further identified occurred in 15 stomachs and may have been of cultivated varieties. No great preference is shown for any one species of wild berry, but mulberries, woodbine, fox grapes, and sour gum were found in the most stomachs.

Mast amounts to 30.70 per cent and is the largest item of food. Acorns, beechnuts, hazelnuts, and pecans make up most of this 
item. It is eaten throughout the year except during the three summer months. It was found in $17 x$ stomachs, and the greatest consumption appears to be in November, when it reached 67.05 per cent of the month's food, and it does not fall much below this figure until spring. This record for mast eating is the largest of that of any bird of this family except the California woodpecker. In most cases where birds eat much mast they habitually store up nuts and seeds for future use. The writer has been able to find but one reference to such a habit in this bird. TW. L. Dawson, in Birds of Ohio, page 357, 1903, says it "lays up frugal stores of mast and corn." This seems quite probable, in view of what is found in the stomachs. Poison iry seeds amount to 2.15 per cent and are eaten in every month from August to February, inclusive.

The following fruits and seeds were found in the stomachs:

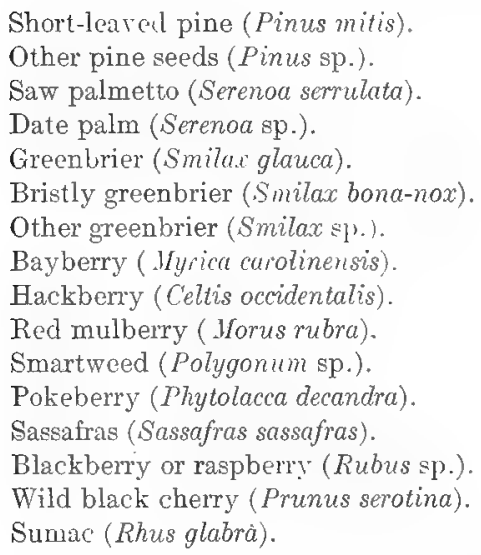

Poison iry (Rhus radicans).

American holly (Ilex opaca).

Swamp holly (Ilex decidua).

Frost grape (I itis cordifolia).

Fox grape (Vitis vulpina).

Woodbine (Parthenocissus quinquefolia).

Prickly pear (Opuntia sp.).

Wild sarsaparilla (.trulia nudicaulis).

Flowering dogwood (Cornus florida).

Rough-leaved dogwood (Comus asperifolia).

Panicled dogwood (Cormus candidissima).

Sour gum ( Nyssa sylvatica).

Huckleberry (Vaccinium sp.).

Elderberry (Sambucus canadensis).

Ragweed (Ambrosia sp.).

Summary.-Only one element in the food of the red-bellied woodpecker has much economic significance. The bird erinces a decided taste for fruit, and sometimes injures orchards, as in Florida orange groves. The contents of the stomachs, however, show that wild fruits are the favorites, and probably only when these have been replaced by cultivated ones is any mischief done. Orange pulp was not positively identified in any stomach, though quite a numberwere collected in Florida during the orange season. Only a little of the grain eaten is taken when it is a loss to the farmer. In its animal food the bird is almost entirely beneficial, as the insects eaten are largely noxious.

\section{FLICKER.}

(Colaptes auratus subspp.)

The flicker (Pl. VI), known also as the golden-winged woodpecker, yellow-shafted woodpecker, high-holder, yellow-hammer, pigeon woodpecker, and hairy-wicket, is one of the most widely distributed and best known species in the United States. This is one of the few 
woodpeckers whose flesh is considered palatable, and a few years ago large numbers were shot for market every fall when wild black cherries were ripe. The bird is so fond of this fruit that when feeding in the trees it loses its natural shyness and is easily approached and killed. Fortunately it is now protected by law in most of the States, and it should be in all. It is a bird of the open country rather than of the forest. It is much more wary than the hairy or downy. It visits the orchard regularly, but does not make serious inroads on the fruit, and it forages much upon the ground-in fact, in spite of its liking for tall trees, the flicker is the most terrestrial of American woodpeckers.

This species is distributed over the whole of the eastern United States and north to Canada and Alaska, and is replaced in the West by the red-shafted flicker. The two forms meet on the Great Plains and along the eastern edge of the Rocky Mountain region and intermingle in all degrees of hybridism. Typical specimens of either species are frequently taken far within the range of the other, as, for instance, a perfect Colaptes auratus was collected by the writer a few miles east of Haywards, Cal., while typical $C$. cafer collaris can be taken every winter at Ames, Iowa. With the possible exception of the yellow-bellied woodpecker, the eastern flicker is the most migratory American species. In winter it is rarely seen in New England and only in small numbers in the other northern States. As it breeds abundantly in Canada, it becomes very numerous in the northern tier of States in fall when migrating. At this time it subsists largely upon wild cherries and other wild fruits.

The flicker rears from 6 to 10 young in each brood. The nest is built in a cavity excavated in a partially clecayed tree, and is often quite elaborate, but in some cases it is in a hole caused by natural decay, where little or no preparatory work is required. The young find their voices very early in life, and by the time they are a week old make a great outcry every time they receive a visit from their parents or even hear approaching footsteps.

Complaints have been made that the flicker eats corn and cultivated fruit to an injurious extent, but the charges are not very specific, and the stomach contents do not indicate extensive depredations of this kind.

For the investigation of the food of the eastern flicker, 684 stomachs were available. They were collected in 35 States, the District of Columbia, and Canada, and are very evenly distributed through the year. The food consists of 60.92 per cent of animal matter to 39.08 of vegetable. In addition the stomachs contain considerable fine sand, which is probably not taken to aid digestion, but is swallowed accidentally with some kinds of food, notably ants. Quite a quantity of vegetable rubbish is taken in the same way. 
Animal food.-Predaceous ground beetles (Carabidæ) form a small but very constant element of the flicker's food. Among those eaten are some of the larger and more predatory genera, such as Calosoma, Scarites, and Pterostichus. The total amount eaten in the year is only 1.62 per cent of the food, and in August, the month of greatest consumption, it rises to only 3.79 per cent. Other beetles are found in the food of every month, but in rather irregular amounts. The aggregate for the year is 3.52 per cent. The favorite food of the flicker, however, is ants. They form the largest item of animal food, not only in the aggregate but in every month. The total for the year is 49.75 per cent of the food. They were found in 524 of the 684 stomachs, i. e., in 76 per cent of the whole, and there were 98 stomachs that contained no other food. The following table shows the importance of ants in the diet of the flicker:

Months.
$\ldots$
$\ldots$

In one case a stomach and crop were both filled with very small ants ('remastogaster sp.). The whole mass was divided with care into 16 parts as nearly equal as possible, and in one part 315 ants were counted, giving 5,040 in one meal of one flicker. In addition there were at least 100 pupæ. Two other stomachs and crops examined in the same way each gave a little over 3,000 ants. Probably each of 100 stomachs in the collection contained nearly as much ant food as these, but the number of ants was less because they were of larger species. A large proportion of the ants eaten are of species that live in the earth, and these appear to be the principal food the flicker obtains on the ground. In every case where the stomach held a quantity of these small ants, a lot of fine sand revealed their source.

Since the flicker destroys so many ants, it may be well to inquire as to the economic bearing of this work. As a rule we do not hear many serious complaints against ants. They do not attack crops or manufactured products. Probably they do some good by devouring dead matter, both animal and vegetable, and in this way hasten the decay of dead trees. On the other hand, some species enter 
houses and become a positive nuisance, as, having their nest in an inaccessible place, it is almost impossible to destroy them. Other species establish colonies in lawns or gardens and are so persistent that nothing short of digging out and carrying off the whole area of earth which they have preempted will rout them from their chosen home. When timber has been injured by wood-boring beetle larvæ, ants enlarge the burrows and in a few years riddle and spoil the whole trunk. The worst sin of the ants, however, is that they protect and foster plant lice in every possible way. They defend them from their enemies, cover them with sheds to shield them from inclement weather, and upon the approach of winter they carry some species into the ground and place them on the roots of plants for the winter and at the return of warm weather bring them to the upper air and place them in a position suitable to their needs. As plant lice constitute one of the worst pests to horticulture, their protectors are a nuisance and should be destroyed. As we have seen, flickers devour enormous numbers of them and aid essentially in holding them in check. Hymenoptera other than ants amount to only four onehundredths of 1 per cent of the yearly food.

Bugs (Hemiptera) are eaten in nearly every month, but only in small quantities. In January, February, and May they reach an average of about 3 per cent, but in no other month do they amount to even 1 per cent. One stomach contained scales not further identified, another held 17 chinch bugs (Blissus leucopterus), and in another were what were probably the same in an early stage of growth. Two stomachs contained each a single bedbug (Cimex lectularius), probably taken on trial and not relished. Cicadas, or harvest flies (Tibicen rimcsa), were found in several stomachs. The aggregate of Hemiptera for the year is only 0.85 per cent.

Orthoptera, in the shape of grasshoppers, crickets, and cockroaches, amount to 2.39 per cent. They are eaten in every month, but not very regularly. Singularly, the maximum quantity was taken in January, 9.77 per cent, which is more than twice the amount in any other month. This record, however, was made by birds taken in Texas, which had partaken freely of crickets. The least consumption occurs in August, the grasshopper month, which shows that the flicker is not a lover of grasshoppers.

Lepidoptera, in the form of caterpillars, are eaten very sparinglyin fact in only three months do they amount to as much as 1 per cent. In August they reach 4.91 per cent, 3.13 in June, and 3.29 in November. The only one identified was the common zebra caterpillar of the gardens (Mamestra picta). The total for the year is 1.28 per cent. A few fly larvæ, spiders, myriapods, crustaceans, and snails make up the rest of the animal food. Larvæ of Tipulidæ (crane flies) were found in 3 stomachs and Bibio larvæ (March flies) in 2. As 
these creatures breed in the earth, this again shows the terrestrial habits of the flicker. Spiders and myriapods were found in a gcod many stomachs, but few were taken at one time, so the aggregate is not large. Crustaceans, in the form of Oniscus (sowbugs), were found in 5 stomachs. Snail shells, mostly fragments, were of frequent occurrence, and one was identified as Zonitoides minusculus. The total of these miscellaneous creatures is 1.49 per cent, which completes the record of animal food.

The following is a list of the insects identified in the stomachs:

COLEOPTERA.

$\checkmark$ 'icindela vulgaris.

Calosoma calidum.

Elaphrus obliteratus.

Scarites subterraneus.

'terostichus sayi.

Limara exarata.

Amara impuncticollis.

Amara angulata.

Calathus ingratus.

Platynus placidus.

Platynus punctiformis.

Brachynus puberulus.

Chlanius sp.

Agonoderus pallipes.

IIarpalus faunus.

Harpalus pennsylvanicus.

Harpalus pleuriticus.

Harpalus ellipsis.

Anisodactylus rusticus.

Anisodactylus sp.

Stenus shoshonis.

Formica obscuripes.

Formica nitidirentris.

Formica subsericea.

Formica subpolita.

Formica gagates.

Formica subrenescens.

Formica sp.

Lcsius claviger.

Lasius aphidicola.

Lasius brevicornis.

Lasius americanus.

Lasius alienus.

Lasius miniatus.

Lasius subniger.

Isasius sp".

Camponotus marginatus.

Camponotus melleus.

Camponotus pennsylvanicus.
Quedius prostrans.

Stelidota 8-maculata.

Melanotus communis.

Copris minutus.

Onthophagus hecate.

Onthophagus sp.

Aphodius fimetarius.

Aphodius inquinatus.

Aphodius bicolor.

Aphodius sp.

Lachnosterna sp.

Ligyrus sp.

Caryoborus arthriticus.

Opatrinus aciculatus.

Blapstinus pruinosus.

Blapstinus pulverulentus.

Blapstinus sp.

Tanymecus confertus.

Sitones hispidulus.

Phytonomus punctatus.

Sphenophorus sp.

HYMENOPTERA (ANTS).

Camponotus minutus.

Camponotus pictus.

Camponotus sp.

Myrmica scabrinodis.

Myrmica sabuleti.

Myrmica sp.

Cremastogaster læviuscula.

Cremastogaster minutissimz

Cremastogaster sp.

Aphænogaster picea.

Aphanogaster fulvum.

Aphanogaster treatæ.

Aphænogaster sp.

Prenolepis imparis.

Pheidole sp.

Solenopsis geminata.

Solenopsis debilis.

Tetramorium sp. 
HEMIPTERA.

Zelus renardi.

Blissus leucopterus.

Metapodius sp.

Bibio sp.

Gryllus sp.

Parastarte triquetra.
Tibicen rimosa.

rimex lectularius.

DIPTERA.

Tipula sp.

LEPIDOPTERA.

Mamestra picta.

ORTHOPTERA.

Ischnoptera sp.

ISOPTERA.

Termes flavipes.

crustacea.

Oniscus sp.

MOLLUSCA.

Zonitoides minusculus.

Vegetable food.-Corn was found in 17 stomachs of the flicker, wheat in one, and buckwheat in two. One stomach taken in March was entirely filled with corn, evidently waste grain. Most of the remainder wis taken in fall and early winter. The total for the year is 1.12 per cent. Small fruits are the favorite vegetable food with this bird. They are eaten in every month and constitute a good percentage in all but two. In April and May fruit amounts to less than 1 per cent, but increases through the summer to October, when it is about 42 per cent of the food, and then decreases gradually to the minimum in April. Possibly some of the Rubus fruits were cultivated, and the cherries in one stomach certainly were, while the fruit pulp in 21 stomachs may have been, but in any case the amount is insignificant and shows that the flicker eats but little domestic fruit. On the other hand, 31 species of wild fruits were identified. They were contained in 265 stomachs, and 40 contained no other food. They are not only the favorite vegetable food, but, next to ants, are the favorite food of the year. There is also shown a fondness for the seeds of various species of poisonous Rhus (poison ivy, poison oak, and poison sumac). These seeds are eaten mostly in the fall and winter months, when small fruits are less abundant. May, June, and July are the only months when none were eaten. November appears to be the month of greatest consumption, when they reach nearly 38 per cent. The aggregate for the year is 9.25 per cent.

Mast, if the term be limited to acorns and other nuts, is not a favorite food of the flicker. It is eaten to some extent in the three 
winter months and occasionally tasted at other times. It amounts to 1.79 per cent of the food. Cambium, weed seed, nonpoisonous Rhus seeds, and rubbish are found in some stomachs pretty regularly through the year, though the quantity is very irregular. It would appear that the three former are eaten only in default of anything better, and the last is probably taken accidentally when seeking ants in rotten wood or under rubbish. The total amount is 6.64 per cent and completes the quota of vegetable food.

The following fruits and seeds were identified:

\begin{tabular}{|c|c|c|}
\hline $\begin{array}{l}\text { Number } \\
\text { stomact } \\
\text { containi }\end{array}$ & & $\begin{array}{l}\text { stomad } \\
\text { contain }\end{array}$ \\
\hline Hemlock (foliage) (Tsuga canadensis). & 1 & White clover (Trifolium repens)..... \\
\hline Red cedar (Juniperus virginiana).... & 5 & Crane's-bill (Geranium sp.)... \\
\hline Barnyard grass (Panicum sp.)...... & 1 & Croton (Croton sp.).......... \\
\hline Foxtail grass (Ixophorus sp.)........ & 2 & Dwarf sumac (Rhus copallina). \\
\hline Glancous-leaved greenbrier (Smilar & & Smooth sumac (Rhus glabra) ......... \\
\hline $\begin{array}{c}\text { glauca }) \ldots \ldots \ldots \ldots \ldots \ldots \ldots \\
\text { Cat brier }(\text { Smilax rotundifolia }) . \ldots \ldots\end{array}$ & $\begin{array}{l}1 \\
1\end{array}$ & $\begin{array}{l}\text { Poison sumac (Rhus vernix)......... } \\
\text { Poison ivy (Rhus radicans)........... }\end{array}$ \\
\hline Bristly greenbrier (Smilar bona-nox). & I & Poison oak (Rhus diversitoba)....... \\
\hline 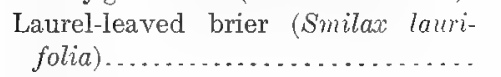 & & $\begin{array}{l}\text { Sumac ( } R \text { hus sp.) ................ } \\
\text { American holly (Iler opaca) . . . . . }\end{array}$ \\
\hline Bayberry (Hyrica carolinensis)...... & 48 & Dahoon holly (Ilcx cassine)......... \\
\hline Pern (Compionia peregrina).... & 1 & $y($ Ilex glabra $)$. \\
\hline (Fagus americana). & 1 & olly (Ilex decidua). \\
\hline Hackberry (Celtis occidentalis)...... & 24 & r (Ilex verticillata $).$ \\
\hline Mulberry (Morus rubra)............ & 2 & bush (Enonymus sp.)..... \\
\hline sicaria (Polygonum lapathi- & & ape (Iitis cordifolia)........ \\
\hline & 1 & dogwood (Cornus florida). \\
\hline 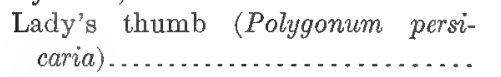 & 1 & 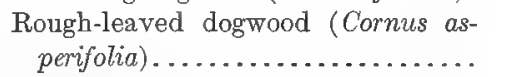 \\
\hline 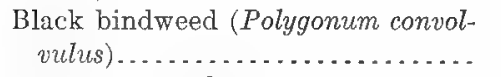 & 1 & 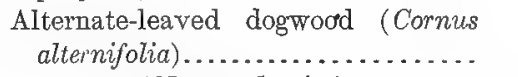 \\
\hline ed (Polygonum sp.). & 4 & Sour gum (Nyssa sylvatica)... \\
\hline d (Phytolacca decandra)..... & 5 & $o$ (Nyssa aquatica).. \\
\hline (Magnolia foetida)........ & 3 & (Gaylussacia sp.).... \\
\hline in benzoin).......... & 2 & nium sp.)... \\
\hline (Rubus cuneifolius). & 1 & Black nightshade (Solanum nigrum). \\
\hline raspberry (Rubus sp.). & 15 & Mullein (Verbascum thapsus)........ \\
\hline Juneberry (Amelanchier canadensis).. & 3 & Black elderberry (Sambucus canaden- \\
\hline Wild black cherry (Prunus serotina). & 30 & \\
\hline Chokecherry (Prun & 7 & Red elderberry (Sambucus pubens).. \\
\hline Crab cherry (Prunus avium). & & Ragweed (Ambrosia artemisiafolia). \\
\hline
\end{tabular}

Summary.-From the point of view of the food analyst the farmer and horticulturist have very little quarrel with the flicker. It eats only a few predaceous ground beetles. The remainder of the animal food is entirely of harmful species. In its vegetable diet, grain and fruit are the only useful products eaten, and the quantities are insignificant. The bird, like many others, has the bad habit of sowing broadcast the seeds of the poison Rhus, but there seems no remedy for this. 


\section{RED-SHAFTED FLICKER.}

\section{(Colaptes cafer collaris and other súbspp.)}

The red-shafted flicker inhabits that part of North America westward from the Great Plains, where its range meets that of the goldenwinged woodpecker. Typical specimens of Colaptes cafer collaris are found as far east as South Dakota, central Iowa, and central Texas. The writer took them in winter at Ames, Iowa, for several years in succession. The eastern and western forms of the flicker nest in the same kind of places, their voices and manner of fligbt are the same, as are their methods of teeding, and practically their food. The differences of plumage can be certainly distinguished only when the bird is near. The western species has one habit which the eastern one rarely shares, that of pecking holes in cornices and cupolas in order to prepare a winter home. As most of the eastern flickers migrate in winter, the few that remain usually find lodging places in trees. In California, where the birds do not migrate in winter, much complaint has been made against them for disfiguring and injuring buildings.

For the investigation of the food of the red-shafted flicker 183 stomachs were available. They were collected in 10 States and in British Columbia, but more than three-fourtlıs of them came from California. They are distributed through every month of the year, but the warmer seasons are represented by entirely too few. The food was found to consist of 67.74 per cent of animal matter to 32.26 of vegetable. This is over 6 per cent more animal food than is eaten by the eastern species. This difference occurs almost entirely in the winter months, when, in the East, the ground is more or less covered with snow and insects are not readily obtained, while seeds and berries are still accessible.

Animal food.- Useful Coleoptera, i. e., predaceous ground beetles, amount to 3.89 per cent of the food, but appear to be eaten very irregularly. In January and March they amount to 17 per cent of the food and in November to 7.28 per cent. In two months they barely reach 1 per cent, and in all the others they are but a trace or do not appear at all. This would seem to indicate that these insects are taken only when better food is not at hand. Other beetles amount to 2.66 per cent. They are largely Scarabæidæ or May beetles, most of them in the larval stage. The larvæ live to a great extent in rotten wood and rubbish, and some species that live on plant roots are often turned up by the plow. They seem to form quite a constant element of the food of both species of flicker. Ants are the favorite food of this bird as well as of its eastern relative. They aggregate 53.82 per cent of the food, which is more than 4 per cent higher than the record of auratus, though it is doubtful if this 
difference would hold with a larger number of stomachs. In May only one stomach of cafer was taken, and it was entirely filled with ants. Like those eaten by auratus, these ants are to a great extent taken from the ground, and the usual quantity of sand was found with them. Ints were found in 127 of the 183 stomachs, and 23 contained no other food. Besides the sand ants, some of the large species that live in decaring trees and logs were eaten. These of course are clug out of their burrows. Hymenoptera other than ants are eaten by this bird so rarcly as to be negligible.

Hemiptera, or bugs, constitute 1.84 per cent of the flicker's diet, but they are so far from being a favorite food that they were found in the stomachs collected in only 4 months-January with 1.92 per cent, April with 12.50 per cent, June with 7.50 per cent, and October with 0.14 per cent. In each of these months the insects were contained in only one stomach and in April and June were all cicadas, or harvest flies, but in the January stomach they consisted of those curious and delicate looking (reatures called lace bugs (Tingitidæ). Caterpillars amount to 2.12 per cent of the food and are mostly eaten in the winter and spring months. This is probably owing to the fact that the species taken are mostly wood borers and are dug out of decaring wood in the colder season. March is the month of greatest consumption with 9.11 per rent, and December next with $\$ . \& 4$ per cent. The amount in the other montlis is small.

Orthoptera aggregate 1.45 per cent and consist of crickets with a few bits of grasshoppers and locusts. They are all taken from October to February inclusive, which shows that this bird, although so terrestrial in its habits, does not join in the grasshopper feast in summer. White ants (Termes), a few other insects, and spiders collectively amount to 1.96 per cent and complete the animal food. Termes are very similar in habits to the true ants, and are often found and deroured by woodpeckers in their search for ants. Like true ants, white ants do much mischief by boring into timber, and are not infrequently found in the woodwork of buildings, which they sometimes greatly injure, even to the extent of threatening the stability of the structure.

The following insects were identified in the stomachs:

COLEOPTERA.

Pterostichus permundus.

Evirthrus orbatus.

Amara insignis.

C'ratathus ruficollis.

Platynus maculicollis.

Axinopalpus biplagiatus.

IIarpalus herbivagus.
Harpalus sp.

Anisodactylus dilatatus.

Anisodactylus piceus.

('horidium histeroides.

Diabrotica soror.

Anthonomus sp.

Calandrinus grandicollis. 
HYMENOPTERA (ANTS).

Formica subpolita.

Formica neorufibarbis.

Formiea obscuricentris.

Formica obscuripes.

Formica sp.

Camponotus marginatus.

Lasius americanus.

Lasius sp.
Cremastogaster lineolata.

Cremastogaster sp.

Solenopsis geminata.

Prenolepis imparis.

Myrmica lobicornis.

Myrmica sp.

Messor andrei.

\section{CRUSTACEA.}

Sowbug (Porcellio scaber).

MOLLUSCA.

Snail (Lymnaa columella).

$V$ egetable food.-Fruit was eaten to the extent of 10.28 per cent of the red-shafted flicker's food. It appears to be taken rather irregularly, but probably examination of a greater number of stomachs would show it to be a pretty regular article of diet, as the eastern flicker is a constant fruit eater. The greatest amount is taken in November, when it aggregated 31.84 per cent. September stands next with 23.75 per cent. Like the eastern species, this bird eats more fruit in fall and winter than in the warmer months. Grapes were identified in 12 stomachs, and probably nearly all were of cultivated varieties. Domestic cherries were found in one stomach, what was thought to be apple pulp in 9, and fruit pulp not further identified in 11. This is the whole list of cultivated fruit, if we suppose the last item to have been of domestic varieties, but as the greater part of it was taken in the winter or late fall months, probably little harm was done. Wild fruits of 6 varieties were found in 10 stomachs. There appear to be less small fruits or berries available for bird food on the western side of the Rocky Mountains than on the eastern. This is well illustrated in the diet of the two flickers; the eastern species has 31 kinds of wild fruit in its bill of fare to 6 of the western bird. This difference has been noted in the food of other closely allied species, one from the East and the other from the West.

Grain amounts to 2.26 per cent of the food. It was found in January, August, October, and November, and consisted of corn in 14 stomachs, barley in 1, and oats in 1. The barley and oats were taken in January, and were therefore waste grain. The corn must have been obtained from the standing crop, and indeed much of it had been eaten while in the milk. This is not, however, a heavy indictment against the flicker and may well be excused. Seeds of various shrubs and herbs and some rubbish amount to 19.59 per cent, and make up the quota of vegetable food. The largest part of this item consists of seeds of the different poisonous Rhuses, commonly 
known as poison ivy or poison oak. They are probably eaten in every month, though the one stomach taken in May did not contain any. They were found in 51 stomachs and formed a staple article of diet in all the cooler months, and in December amounted to more than half the food. It is in the distribution of these seeds, if anywhere, that the flickers do harm. Seeds of the nonpoisonous Rhuses (sumac) and of various weeds were eaten occasionally but not in great quantities. Mast in the shape of acorns was found in 16 stomachs, and is probably very acceptable in the absence of better food.

The following fruits and seeds were identified:

Pigweed (Amaranthus sp.).

Purslane (Portulaca sp.).

Gooseberry (Ribes menziesi).

Bur clover (Medicago denticulatum).

Filaree (Erodium cicutarium).

Poison ivy (Rhus radicans).

Poison ivy (Rhus aromatica).

Poison oak (Rhus diversiloba).
Sumac (Rhus sp.).

Pepper berry (Schinus molle).

Woodbine (Parthenocissus quinquefolia).

Dogwood (Cornus pubescens).

Elder (Sambucus glauca).

Sunflower (Helianthus sp.).

Star thistle (Centaurea calcitrapa).

Bur thistle (Centaurea melitensis).

Summary.-The above analysis of the food shows that the farmer and horticulturist have little to fear from the red-shafted flicker. In its animal diet it does very little harm, and it consumes no more of the products of husbandry than it is entitled to. Its greatest fault is distributing seeds of the poisonous Rhuses, a sin which it shares with so many other birds that there is no occasion for invidious comparisons.

\section{IVORY-BILLED WOODPECKER.}

(Campephilus principalis.)

The ivory-billed is the largest woodpecker inhabiting the United States. Unfortunately, it appears to be rapidly becoming extinct. It originally occupied all the heavily wooded bottom lands from eastern Texas east to the Atlantic and from southern Indiana and Illinois south to the Gulf. At present it is confined to the lower Mississippi Valley and Gulf States and is nowhere numerous.

Only two stomachs of this species have been available for examination. The contents of these are discussed in detail because of the interest that attached to this magnificent but vanishing bird rather than its present economic importance. One stomach contained 32 and the other 20 of the wood-boring cerambycid larvæ, which live by boring into trees. These constituted 37.5 per cent of the whole food. The remainder of the animal food consisted of engraver beetles (Scolytidx) found in one stomach. Of these, three species were identified-Tomicus avulsus, $T$. calligraphus, and $T$. grandicollis. The total animal food amounted to 38.5 per cent. 
The vegetable food consisted of fruit of Magnolia foetida in one stomach, and of pecan nuts in the other. The average for the two was 61.5 per cent. This analysis of food indicates that the species, except for its small numbers, might be of considerable economic value, as the insects forming the animal portion of the food are mostly of an injurious character. These powerful birds are able to reach the wood-boring grubs in places where smaller species fail. and their large bodies require a great quantity of such food. The vegetable portion of the food does not indicate that the bird is likely to attack any products of agriculture, an inference which is strengthened by its shy, retiring habits. It is preeminently a wilderness lover and avoids cleared and cultivated districts.

When we see how much good this woodpecker is capable of doing as a guardian of the forest, it seems deplorable that it should be allowed to be exterminated. Wise legislation, backed by intelligent public opinion, may retard, if not absolutely prevent, the present destruction and allow the bird to regain something of its former abundance. There is plenty of room for this splendid species and much need of its services in the great southern forests.

\section{OTHER WOODPECKERS.}

Besides the species of woodpeckers whose food has been discussed in the preceding pages, a few stomachs of 5 other species have been received, and, while there are too few to warrant a general discussion of their food, some mention of its most prominent characteristics may be made. The following table gives the number of stomachs of each species and the percentage of animal and vegetable food for each:

\begin{tabular}{|c|c|c|c|}
\hline Name of species. & $\begin{array}{l}\text { Number of } \\
\text { stomachs. }\end{array}$ & $\begin{array}{l}\text { Animal } \\
\text { food. }\end{array}$ & $\begin{array}{l}\text { Vegetable } \\
\text { food. }\end{array}$ \\
\hline 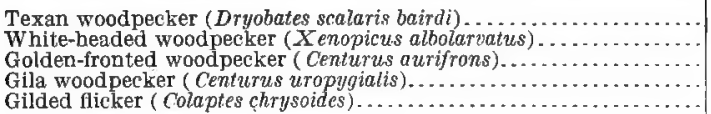 & $\begin{array}{r}14 \\
14 \\
11 \\
1 \\
5\end{array}$ & $\begin{array}{l}92.07 \\
\text { 38. } 93 \\
\text { 54. } 73 \\
\text { 40. } 00 \\
\text { 88. } 00\end{array}$ & $\begin{array}{l}7.93 \\
61.07 \\
45.27 \\
60.00 \\
12.00\end{array}$ \\
\hline
\end{tabular}

The Texan woodpecker (Dryobates s. bairdi) shows the ruling characteristic of the genus in its food, for the largest item is wood-boring beetle larvæ. Caterpillars are second in importance, and include a number of cotton worms (Alabama argillacea), which were found in some stomachs collected in Texas. Ants are next in rank, and these three items make up the bulk of the food.

Half of the animal food of the white-headed woodpecker (Xenopicus albolarvatus) is ants, but the most pronounced characteristic of this bird is its fondness for the seeds of pines, which constitute more than half of the food. 
The golden-fronted woodpeckei (Centurus aurifrons) shows a decirled taste for grasshoppers, which make up half of its animal food. Its vegetable diet is composed almost entirely of small fruits or berries.

The one. stomach of the Gilia woodpecker (Centurus uropygialis) was largely filled with beetles of the May-beetle family, with a few bones of a lizard. The vegetable part was mere refuse.

The gilded flicker (Colaptes chrysoides) shares the characteristic fondness of the genus for ants, which constitute three-fourths of the whole food. The vegetable part was mostly mast. 



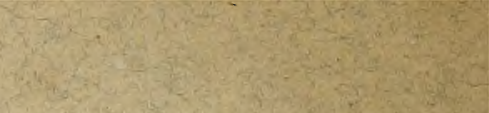

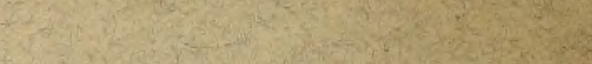

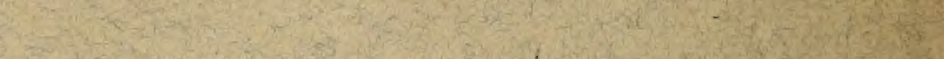

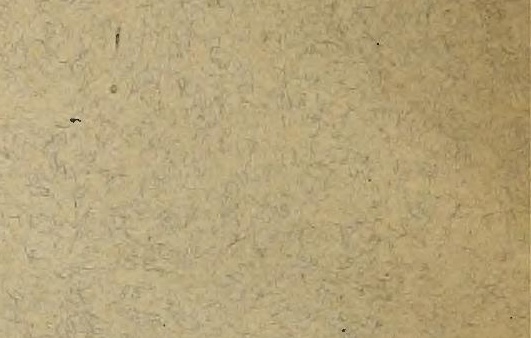

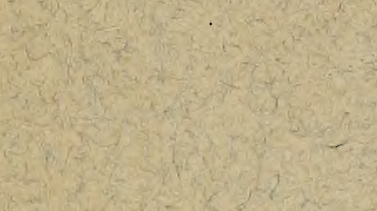

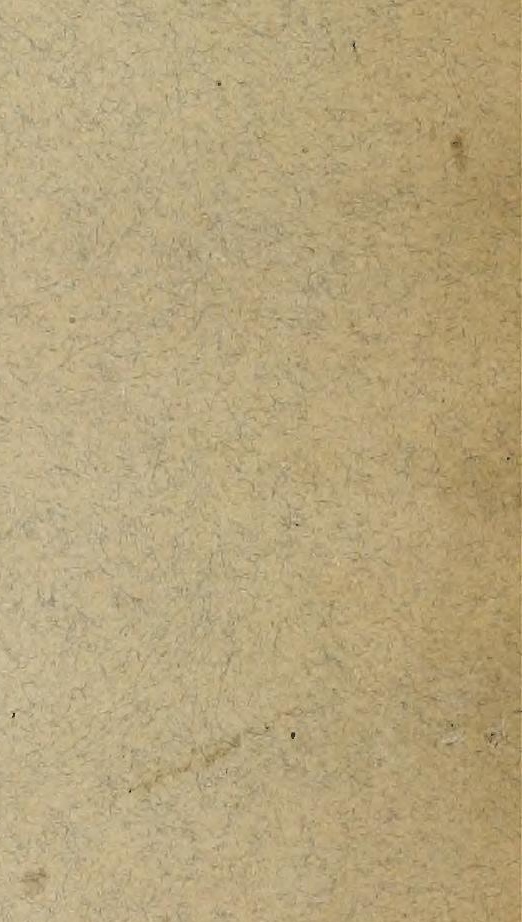
(x) $x^{2}+y^{2}$ (7)

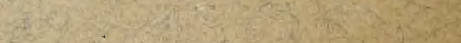

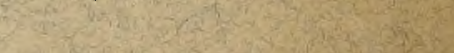
(3) 6.

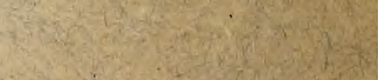

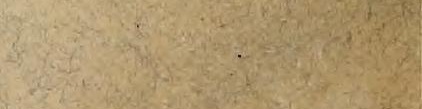
-

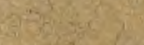

